OPEN ACCESS

Edited by:

Florent Rivals,

Catalan Institution for Research

and Advanced Studies (ICREA), Spain

Reviewed by:

Zach Farris,

Appalachian State University,

United States

Robert S. Feranec,

New York State Museum

United States

${ }^{*}$ Correspondence:

Sean W. Hixon

hixon@ucsb.edu

Specialty section:

This article was submitted to

Paleoecology,

a section of the journal

Frontiers in Ecology and Evolution

Received: 01 April 2021

Accepted: 07 June 2021

Published: 30 June 2021

Citation:

Hixon SW, Douglass KG Godfrey $L R$, Eccles L, Crowley BE, Rakotozafy LMA, Clark G, Haberle S,

Anderson A, Wright HT and

Kennett DJ (2021) Ecological

Consequences of a Millennium

of Introduced Dogs on Madagascar.

Front. Ecol. Evol. 9:689559.

doi: $10.3389 /$ fevo.2021.689559

\section{Ecological Consequences of a Millennium of Introduced Dogs on Madagascar}

\author{
Sean W. Hixon ${ }^{*}$, Kristina G. Douglass ${ }^{2,3,4}$, Laurie R. Godfrey5, Laurie Eccles², \\ Brooke E. Crowley ${ }^{6,7}$, Lucien Marie Aimé Rakotozafy ${ }^{8}$, Geoffrey Clark ${ }^{9}$, Simon Haberle ${ }^{9}$, \\ Atholl Anderson ${ }^{9}$, Henry T. Wright ${ }^{10,11}$ and Douglas J. Kennett ${ }^{1}$
}

${ }^{1}$ Department of Anthropology, University of California, Santa Barbara, Santa Barbara, CA, United States, ${ }^{2}$ Department of Anthropology, Pennsylvania State University, State College, PA, United States, ${ }^{3}$ Institute of Energy and the Environment, Pennsylvania State University, State College, PA, United States, ${ }^{4}$ Max Planck Institute for the Science of Human History, Jena, Germany, ${ }^{5}$ Department of Anthropology, University of Massachusetts, Amherst, MA, United States, ${ }^{6}$ Department of Geology, University of Cincinnati, Cincinnati, $\mathrm{OH}$, United States, ${ }^{7}$ Department of Anthropology, University of Cincinnati, Cincinnati, $\mathrm{OH}$, United States, ${ }^{8}$ Institute of Civilizations, Museum of Art and Archaeology, University of Antananarivo, Antananarivo, Madagascar, ${ }^{9}$ Department of Archaeology and Natural History, College of Asia and the Pacific, The Australian National University, Canberra, ACT, Australia, ${ }^{10}$ Museum of Anthropological Archaeology, University of Michigan, Ann Arbor, MI, United States, ${ }^{11}$ Santa Fe Institute, Santa Fe, NM, United States

Introduced predators currently threaten endemic animals on Madagascar through predation, facilitation of human-led hunts, competition, and disease transmission, but the antiquity and past consequences of these introductions are poorly known. We use directly radiocarbon dated bones of introduced dogs (Canis familiaris) to test whether dogs could have aided human-led hunts of the island's extinct megafauna. We compare carbon and nitrogen isotope data from the bone collagen of dogs and endemic "fosa" (Cryptoprocta spp.) in central and southwestern Madagascar to test for competition between introduced and endemic predators. The distinct isotopic niches of dogs and fosa suggest that any past antagonistic relationship between these predators did not follow from predation or competition for shared prey. Radiocarbon dates confirm that dogs have been present on Madagascar for over a millennium and suggest that they at least briefly co-occurred with the island's extinct megafauna, which included giant lemurs, elephant birds, and pygmy hippopotamuses. Today, dogs share a mutualism with pastoralists who also occasionally hunt endemic vertebrates, and similar behavior is reflected in deposits at several Malagasy paleontological sites that contain dog and livestock bones along with butchered bones of extinct megafauna and extant lemurs. Dogs on Madagascar have had a wide range of diets during the past millennium, but relatively high stable carbon isotope values suggest few individuals relied primarily on forest bushmeat. Our newly generated data suggest that dogs were part of a suite of animal introductions beginning over a millennium ago that coincided with widespread landscape transformation and megafaunal extinction.

Keywords: radiocarbon dating, $\delta 15 \mathrm{~N}, \delta 13 \mathrm{C}$, exclusion competition, predation, fosa, extinction, bushmeat 


\section{INTRODUCTION}

Madagascar is a biodiversity hotspot that has repeatedly faced a variety of biological invasions over the past millennium (Middleton, 1999; Kolby, 2014; Hixon et al., submitted). A debate regarding when humans first arrived on Madagascar is ongoing, with some researchers favoring early human arrival 10,0004,000 years ago based on rare stone tools and cutmarks on ancient elephant bird bone (Dewar et al., 2013; Hansford et al., 2018), and other researchers favoring recent arrival 1,600-1,000 years ago based on broader cultural considerations (Anderson et al., 2018). Endemic vertebrates $>10 \mathrm{~kg}$ declined by $\sim 950$ years ago (Crowley, 2010), and over half of the island's surface is currently dedicated to pastoralism that involves introduced zebu cattle (Anonymous, 2003). Hunting, deforestation, and regional aridification help explain aspects of past extinctions (Burney et al., 2004; Virah-Sawmy et al., 2010; Crowley et al., 2017; Anderson et al., 2018; Hixon et al., 2018; Godfrey et al., 2019; Faina et al., 2021; Godfrey and Douglass, 2021), and interactions with introduced species (e.g., livestock, rodents, and predators) could have exacerbated these stressors (Dewar, 1997; Hixon et al., submitted). Globally, changes in human land use (i.e., the spread of pastoralism and commensal species) generally coincide with past environmental transformations (Stephens et al., 2019) that contribute to biotic homogenization (McKinney, 1997; McKinney and Lockwood, 1999). As part of this transformation, introduced predators can disrupt island ecosystems by facilitating human hunting, creating novel predation pressure, and competing with other predators (e.g., competition between dingoes and red foxes in Australia; Cupples et al., 2011), yet we know very little about the antiquity of introduced predators on Madagascar.

We use radiocarbon $\left({ }^{14} \mathrm{C}\right)$ and stable isotope $\left(\delta^{13} \mathrm{C}\right.$ and $\delta^{15} \mathrm{~N}$ ) data from bone collagen to test the following hypotheses: (1) introduced dogs (Canis familiaris) preyed on lemurs, and (2) dogs competed with the island's largest endemic carnivores (Cryptoprocta spp., the fosa). Limited chronological overlap (as inferred from directly ${ }^{14} \mathrm{C}$-dated dog and lemur bones) would reduce the potential for dogs to have aided hunting of extinct lemurs, and lack of isotopic niche overlap among dogs and Cryptoprocta spp. would diminish the potential for direct forms of competition. However, lack of dietary overlap would not necessarily exclude the possibility that dogs interacted aggressively with Cryptoprocta spp. or facilitated human-led hunts of prey that Cryptoprocta spp. also hunted. This work expands our understanding of both past megafaunal extinction and modern functional diversity of predators on Madagascar.

Madagascar's endemic family of carnivorans (Eupleridae) includes ten extant species that range in size from the $\sim 550 \mathrm{~g}$ broad-striped vontsira (Galidictis fasciata) to the $\sim 8.5 \mathrm{~kg}$ fosa (Cryptoprocta ferox, Wampole et al., 2021). The so-called "cave" fosa (Cryptoprocta spelea, thought to be extinct) was likely double the size of C. ferox (Goodman et al., 2004) and may still exist in remote parts of northern Madagascar (Nomenjanahary et al., 2021). All members of Eupleridae are currently threatened, and the IUCN red list currently includes C. ferox as vulnerable due to rapid population decline (Hawkins and Racey, 2008).
Introduced mammalian predators include dogs, cats (Felis spp.), and the small Indian civet (Viverricula indica, Figure 1), yet only relatively large predators (dogs and Cryptoprocta spp.) are reasonably well represented in Madagascar's subfossil record (Rakotozafy and Goodman, 2005; Crowley, 2010). It is not known when dogs first colonized the island (Figure 2, Crowley, 2010; Douglass et al., 2019), and traces of predation by dogs on subfossil bones (e.g., gnaw marks) are understudied and possibly cryptic (Brockman et al., 2008). A rare set of cave rock drawings in western Madagascar may depict a hunting scene that includes dogs, an extinct sloth lemur, and symbols that have parallels from around the Indian Ocean, but the age of these drawings is uncertain (Burney et al., 2020). Madagascar's modern dogs have primarily African ancestry (Ardalan et al., 2015), which is consistent with the Bantu origin of the most common Malagasy word for dog (amboa, Blench, 2008).

Dog diet on Madagascar is poorly characterized. Modern and historic surveys suggest dogs rely heavily on plant and animal scraps in human derived food waste (Decary, 1939; Kshirsagar et al., 2020). Yet dogs are also known to stalk lemurs (Brockman et al., 2008) and help humans hunt a variety of bushmeat (Supplementary Dataset 2, Decary, 1939; Garcia and Goodman, 2003; Gardner and Davies, 2014). Dogs in at least SW and NW Madagascar currently subsist largely on food scraps, and people often feed hunting dogs the innards of bushmeat (Godfrey et al., submitted, Thompson and Borgerson, pers. comm.). Dogs are popular protection animals around Ranomafana National Park, in central Madagascar (Kshirsagar et al., 2020). However, dogs can also transmit rabies and form a general nuisance while they scavenge (Rajeev et al., 2019). Some dog owners have reported that their dogs harass and kill C. ferox around Ranomafana (Valenta et al., 2016; Kshirsagar et al., 2020). Data from live traps and camera traps suggest that C. ferox avoids dogs in several national parks (Figure 1), which may follow from a combination of aggressive interactions and disease transmission (Dollar et al., 2007; Barcala, 2009; Gerber et al., 2012; Farris et al., 2015; Pomerantz et al., 2016; Rasambainarivo et al., 2017; Merson et al., 2019a). For example, C. ferox is typically cathemeral, yet individuals around Ankarafantsika in the NW and Masoala-Makira in the east tend to be primarily nocturnal, where dogs are active during the dawn and day (Farris et al., 2015; Merson et al., 2019a). Additionally, C. ferox captures increased following the euthanasia of dogs at Ankarafantsika (Barcala, 2009), which suggests that interactions involving dogs affect both C. ferox abundance and activity patterns.

Madagascar's modern dogs have at least some dietary overlap with $C$. ferox that creates potential for exploitation competition (Farris et al., 2017; Merson et al., 2019a). Data from modern kill sites and C. ferox scat from multiple ecoregions in Madagascar indicate that they are opportunistic predators with the potential for heavy reliance on lemurs (Supplementary Dataset 3, Rasoloarison et al., 1995; Wright et al., 1997; Goodman et al., 1997; Dollar et al., 2007; Hawkins and Racey, 2008). Modern C. ferox and dogs are both known to consume sifakas (e.g., Propithecus verreauxi), tenrecs, rodents, birds (e.g., chicken and coua), frogs, snakes, and scraps of bushpigs and 


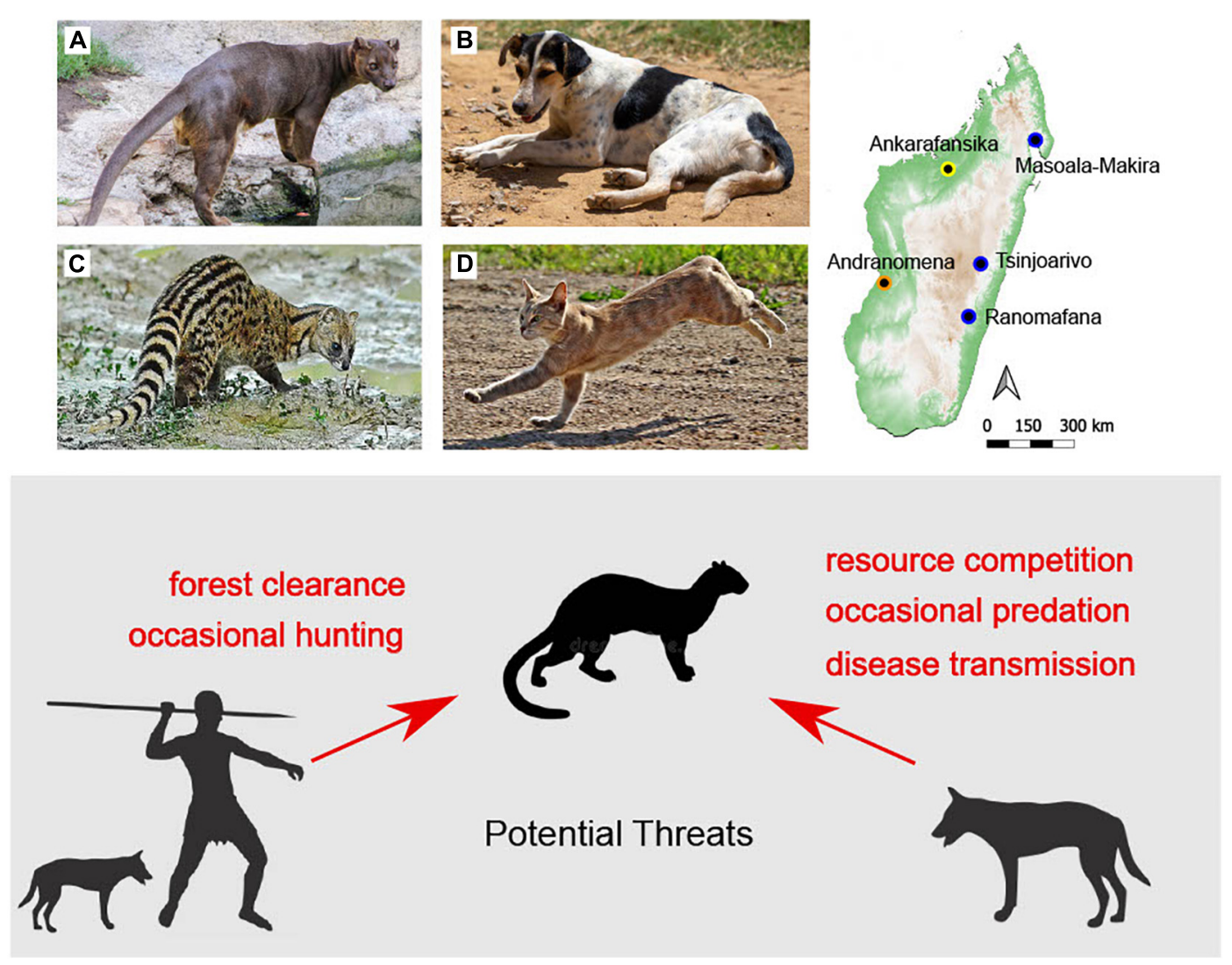

FIGURE 1 | Endemic fosa (A, Cryptoprocta ferox) may interact with introduced dogs (B, Canis familiaris), Indian civets (C, Viverricula indica), and cats (D, Felis sp.). National parks discussed in the text where antagonistic interactions between introduced and endemic predators have been observed are shown in the map at right. The ecoregion for each park is denoted using colors (orange = succulent woodland, yellow $=$ dry deciduous forest, blue $=$ central highlands and humid forest). Human and introduced predator threats to C. ferox are summarized in shaded area below.

zebu cattle (Figure 2, Decary, 1939; Rasoloarison et al., 1995; Goodman et al., 1997; Brockman et al., 2008; Hawkins and Racey, 2008; Gardner and Davies, 2014; Valenta et al., 2016). There is no published evidence for omnivory by $C$. ferox beyond possible occasional fruit consumption as a source of water during the dry season (Hawkins and Racey, 2008). Dogs raid bird and reptile nests and can engage in devastating amounts of surplus killing. Though they are typically more inefficient hunters than wild canids (Butler et al., 2004; Serpell and Barrett, 2017), their impacts can still be considerable. For example, a single stray dog killed hundreds of North Island brown kiwis (Apteryx mantelli, $>50 \%$ of the local population) in New Zealand within a couple of months (Taborsky, 1988). The dramatic impact that dogs can have on their prey may diminish prey for $C$. ferox.

Exclusion competition between dogs and C. ferox follows from the potential for aggressive encounters and occurs regardless of impacts on prey populations. Dogs are avid chasers that contribute to habitat fragmentation by inducing fear and avoidance in a wide range of animals (Lenth et al., 2008; Young et al., 2011; Ritchie et al., 2014). Dogs associated with human hunters increase the potential for exclusion competition with native predators throughout Madagascar. Some evidence of the past association of dogs with human hunters (Burney et al., 2020) suggests that there may be a history of exclusion competition between dogs and Cryptoprocta spp.

Radiocarbon and stable isotope data from bone collagen can give a long-term perspective on predator interactions and clarify past and ongoing processes that influence endemic biodiversity. Based on the potential association of dog bones with extinct megafauna from paleontological sites (Douglass et al., 2019), we expect some chronological overlap among these animals. We also expect some overlap in dog and Cryptoprocta spp. isotope values. Animals with similar diets that forage in similar habitats have tissues with similar $\delta^{13} \mathrm{C}$ and $\delta^{15} \mathrm{~N}$ values (reviewed in Crawford et al., 2008). Carbon isotope values predominantly reflect the plants at the base of the food web (Farquhar et al., 1989; Marshall et al., 2007). Plants that use the $C_{3}$ photosynthetic pathway (primarily trees, shrubs, and herbs) tend to be depleted in ${ }^{13} \mathrm{C}$ by over $10 \%$ relative to plants that use the $\mathrm{C}_{4}$ pathway (primarily grasses) or the CAM pathway (primarily succulents). Data from sympatric $\mathrm{C}_{3}, \mathrm{C}_{4}$, and CAM plants from $\mathrm{SW}$ Madagascar reflect this difference, with combined CAM and $\mathrm{C}_{4}$ plant tissue $\left(\delta^{13} \mathrm{C}\right.$ $\mu \pm \sigma=-12.8 \pm 1.6 \%$ ) enriched in ${ }^{13} \mathrm{C}$ by $\sim 15 \%$ relative to $\mathrm{C}_{3}$ plant tissue ( $\mu \pm \sigma=-27.2 \pm 2.3 \%$, Hixon et al., submitted). To a lesser extent, plant $\delta^{13} \mathrm{C}$ values also depend on variables such as canopy cover, moisture availability, salinity, and soil microbe 


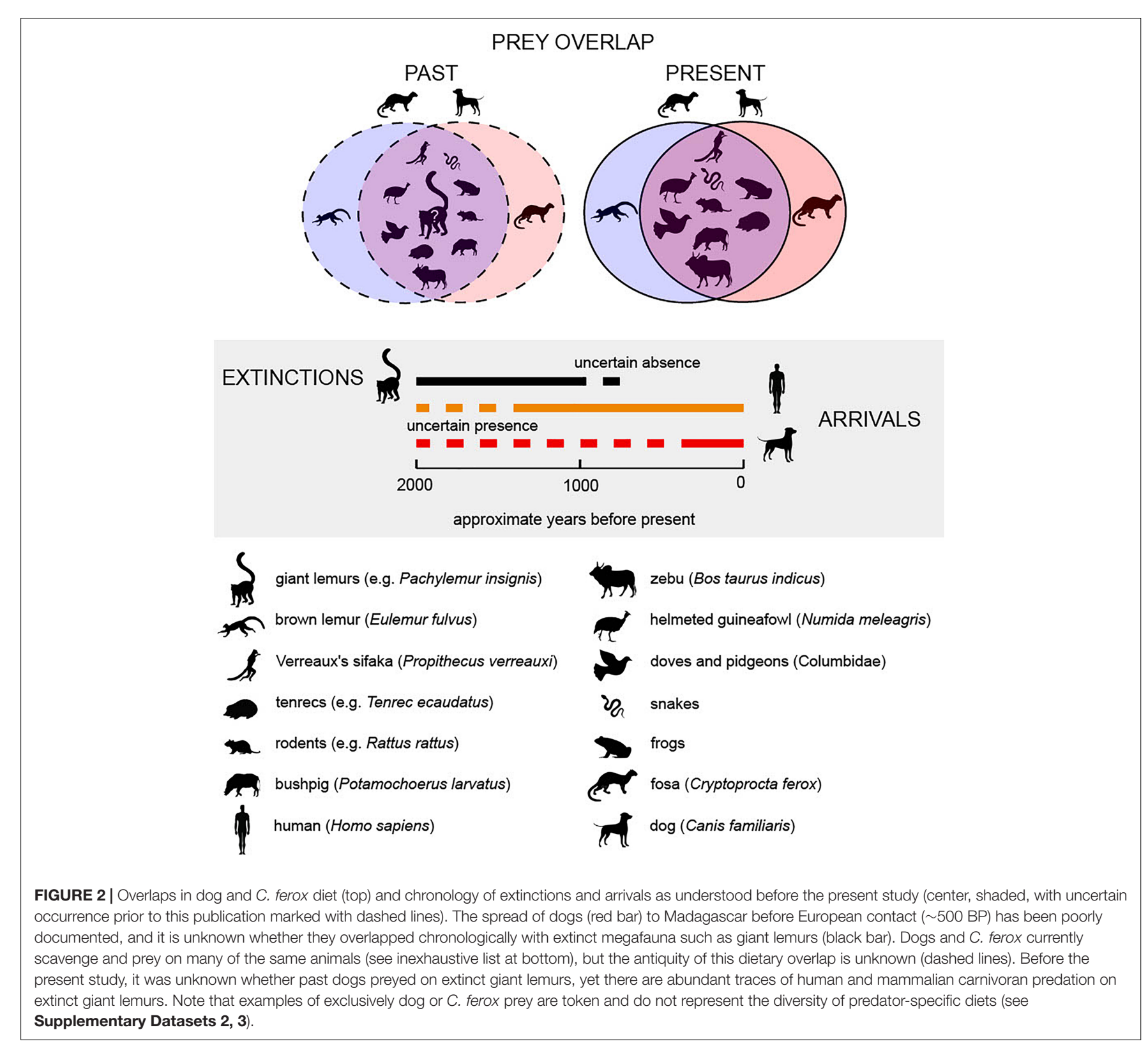

respiration (reviewed in Farquhar et al., 1989). These patterns are passed on to herbivores and higher order consumers over time. If both dogs and Cryptoprocta spp. consumed forest-dwelling herbivores (such as most of the island's extinct megaherbivores), then we would expect overlap in collagen $\delta^{13} \mathrm{C}$ values among these groups (Godfrey and Crowley, 2016). Alternatively, if dogs regularly consumed scraps of introduced grazers (e.g., zebu cattle and ovicaprids), then we would expect dogs to have relatively high collagen $\delta^{13} \mathrm{C}$ values and minimal overlap with Cryptoprocta spp.

We also expect overlap in collagen $\delta^{15} \mathrm{~N}$ values among co-occurring dogs and Cryptoprocta spp. Consumer tissues tend to be enriched in ${ }^{15} \mathrm{~N}$ relative to diet such that each increase in trophic level corresponds to a 3-5\% increase in collagen $\delta^{15} \mathrm{~N}$ values (Cleland, 2001; McCutchan et al., 2003;
Hyodo et al., 2010). As secondary consumers, dogs and Cryptoprocta spp. should have comparable $\delta^{15} \mathrm{~N}$ values, though omnivory or the preferential consumption of certain prey tissue (e.g., intestines) may reduce $\operatorname{dog} \delta^{15} \mathrm{~N}$ values relative to Cryptoprocta spp. $\delta^{15} \mathrm{~N}$ values (Reid and Koch, 2017). Soil nitrogen cycling also strongly influences ecosystem $\delta^{15} \mathrm{~N}$ values and is sensitive to moisture availability (Austin and Vitousek, 1998), so both plant and consumer $\delta^{15} \mathrm{~N}$ values vary considerably among ecoregions in Madagascar (Crowley et al., 2011). Specifically, values are highest in the xerophytic spiny thicket in SW Madagascar and lowest in the humid forests in the east and north. There can also be pronounced differences among microhabitats in the same region (Crowley et al., 2012, 2014; Heck et al., 2016). Plants and animals living on saline coastal soils that are influenced by marine-derived nitrates may 
also have higher $\delta^{15} \mathrm{~N}$ values than those that live inland (Heaton, 1987; Sparks and Crowley, 2018; Mosher et al., 2020; Hixon et al., submitted). Thus, only in comparable environments can consumer $\delta^{15} \mathrm{~N}$ values be interpreted primarily in terms of diet.

\section{MATERIALS AND METHODS}

\section{Specimen and Site Selection}

Sampled dog bones come from 13 sites spread throughout Madagascar (Figure 3 and Supplementary Datasets 1, 4). We sampled all available bones from existing collections $(n=16$ subfossils +3 modern dog bones). Most specimens $(n=12)$ are housed at the University of Antananarivo; others are curated at the National Museum of Natural History, Paris as well as Yale University, the University of Massachusetts, Amherst, and the University of California at Santa Barbara (Supplementary Dataset 1). These bones were collected from both archeological sites (Rezoky, Andranosoa, and Lakato'ni Gavin) and paleontological sites (e.g., Andolonomby and Tsirave) that span four of Madagascar's five major ecoregions but are concentrated in the spiny thicket and succulent woodland of the southwest (Figure 3). We also analyzed two subfossil C. ferox bones from Taolambiby that are currently housed at the Australian National University (ANU). To augment these datasets, we compiled previously published data from five dogs (includes two modern bones, Crowley, 2010; Douglass et al., 2019), nine subfossil C. ferox (Crowley, 2010; Crowley and Godfrey, 2013; Crowley et al., 2017; Anderson et al., 2018), and three subfossil C. spelea (Crowley, 2010). Note that all subfossil Cryptoprocta spp. come from paleontological sites and that all but one of the previously published predators (a subfossil C. ferox, OxA 27174) have both $\delta^{13} \mathrm{C}$ and $\delta^{15} \mathrm{~N}$ data.

To compare an estimated time of dog introduction with hunting and extinction chronologies (see section "Data Analysis" below), we also compiled previously published ${ }^{14} \mathrm{C}$ data from butchered bone of multiple endemic taxa from SW Madagascar (extinct giant lemurs, an extant lemur consumed by C. ferox (P. verreauxi), elephant birds, and pygmy hippo, (Supplementary Dataset 1) and three species of giant lemurs with relatively large sample sizes ( $n \geq 20$ each, Pachylemur insignis, Archaeolemur majori, and Palaeopropithecus ingens, all from SW Madagascar, Supplementary Dataset 1). We focus on the arid SW, because each ecoregion has its own chronology of species introductions and extinctions, and most existing ${ }^{14} \mathrm{C}$ datasets come from this ecoregion (Crowley, 2010; Douglass et al., 2019). We focus on comparing dog and Cryptoprocta spp. data with those from extinct giant lemurs, because (1) there is widespread evidence that at least Cryptoprocta spp. and humans preyed on these animals (Meador et al., 2019; Godfrey et al., submitted), and (2) these taxa have robust ${ }^{14} \mathrm{C}$ chronologies that suggest they disappeared at approximately the same time as other megafauna such as pygmy hippos and giant tortoises (Crowley, 2010; Hixon et al., submitted). To help infer past $\operatorname{dog}$ and C. ferox diet, we compiled published lists of prey species from across the island (Supplementary Datasets 2, 3). We make stable isotope comparisons involving prey taxa within the arid SW

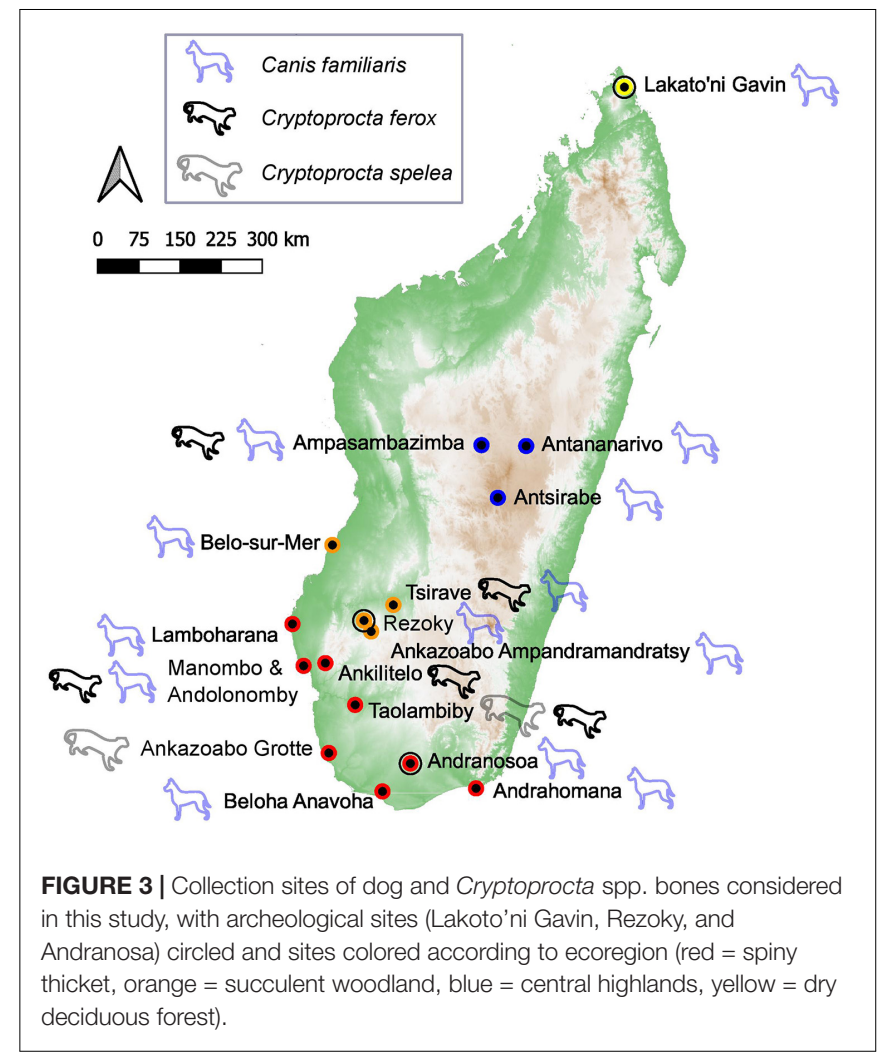

(Supplementary Dataset 1), and we also focus on subfossil bone, because few of our sampled specimens are modern, and some extant and introduced taxa likely shifted their diet and habitat use in response to the recent expansion of grasslands on the island (Crowley and Samonds, 2013). The previously published literature includes 298 potential prey individuals with stable isotope data from the SW, and we include unpublished records from 11 individuals in our dataset (analyzed previously by B.E.C. using approach from Sparks and Crowley, 2018). We further expanded this dataset by sampling bones from an additional 13 potential prey individuals from Taolambiby and Lamboharana/Lamboara in SW Madagascar, which brings the potential prey total to 311 individuals. During analyses, we excluded 21 previously published data from specimens that (1) lack explicit reference to bone collagen purification protocols or (2) include signs of contamination (i.e., atomic C:N > 3.5, Brock et al., 2010).

\section{${ }^{14} \mathrm{C}$ and Stable Isotope Analyses}

Pretreatment of the 31 subfossil and three modern specimens took place in the Human Paleoecology and Isotope Geochemistry Laboratory at Pennsylvania State University (PSU). Prior to demineralization, bones sampled from museum collections suspected of using ink labels and conservants/consolidants such as polyvinyl acetate must go through solvent rinses to remove exogenous carbon with distinct ${ }^{14} \mathrm{C}$ content and $\delta^{13} \mathrm{C}$ values (France et al., 2011). We sonicated museum specimens in sequential washes of methanol $(\mathrm{MeOH})$, acetone, dichloromethane (DCM), and nanopure water. Samples were 
sonicated in $20 \mathrm{~mL}$ of each fluid for $20 \mathrm{~min}$. For the three modern bone samples, we removed lipids using $3 \times$ sonication in 2:1 DCM:MeOH followed by $3 \times$ rinsing in nanopure water (modified from Guiry et al., 2016).

All bones were mechanically cleaned, demineralized in 0.5 $\mathrm{N}$ hydrochloric acid $(\mathrm{HCl})$ under refrigeration, and gelatinized in $0.01 \mathrm{~N} \mathrm{HCl}$ at $60^{\circ} \mathrm{C}$. Collagen from the bone of subfossil individuals was purified through ultrafiltration (14 samples, Beaumont et al., 2010; Fernandes et al., 2021) or purification with XAD resin (17 samples, Supplementary Dataset 1, Stafford et al., 1988, 1991; Lohse et al., 2014). When collagen is relatively intact and yields are high, ultrafiltration can purify a sample by mechanically removing the smaller $(<30 \mathrm{kDa})$ fraction, which includes degraded collagen and exogenous contaminants (Higham et al., 2006). When collagen is stained or degraded, the relatively less polar contaminants (humates, in particular) can be separated chromatographically by passing the hydrolyzed sample through a column filled with XAD resin (Stafford et al., 1988).

Stable isotope data were obtained at Yale University's W.M. Keck Biotechnology Resource Laboratory, the University of Cincinnati's Stable Isotope Laboratory, and the University of New Mexico's Center for Stable Isotopes (Supplementary Dataset 1). Secondary standards from each lab were used to correct data using two-point normalization, and the mean accuracy of $\delta^{13} \mathrm{C}$ and $\delta^{15} \mathrm{~N}$ measurements across runs was $\leq 0.3 \%$. Standard quality assurance data indicate that the mean precision of $\delta^{13} \mathrm{C}$ and $\delta^{15} \mathrm{~N}$ measurements across runs was $\leq 0.3$ and $\leq 0.2 \%$, respectively.

We confirmed sample quality and collagen preservation using percent collagen yield, atomic C:N, $\delta^{13} \mathrm{C}$ values, and $\delta^{15} \mathrm{~N}$ values prior to AMS ${ }^{14} \mathrm{C}$ measurement (DeNiro, 1985; Van Klinken, 1999; Beaumont et al., 2010; Kennett et al., 2017). Residual contaminants can have distinct $\mathrm{C}: \mathrm{N}$ and stable isotope values, and this was the case for one sample (a dog from Rezoky, sample ID "615," which was not dated and not further considered; see Supplementary Dataset 1). We graphitized collagen from the remaining 30 subfossil specimens at PSU and submitted graphite for ${ }^{14} \mathrm{C}$ analysis at the Pennsylvania State University AMS facility and UC Irvine's W.M. Keck Carbon Cycle AMS (Supplementary Dataset 1).

\section{Data Analysis}

We calibrated radiocarbon dates in OxCal 4.4 using the Southern Hemisphere calibration curve SHCal20 (Hogg et al., 2020), or the post-bomb atmospheric SH3 curve (Hua et al., 2013) for three dogs that yielded $>{ }^{14} \mathrm{C}$ modern ages (Supplementary Dataset 1). We used both classical frequentist and Bayesian statistical approaches to event estimation to compare estimated times of dog introduction and lemur extinctions (Buck and Bard, 2007; Bradshaw et al., 2012).

Our Bayesian approach starts with the assumption that dateable material was deposited uniformly during the past several thousand years. This assumption is conservative and underestimates the true degree of temporal overlap between introduced and extinct taxa. Extinctions actually involve a period of declining population (and decreasing rate of deposition), while introductions tend to involve a period of expanding population (and increasing rate of deposition). Both approaches produce confidence/credible intervals for extinction and introduction events. Note that, in the case of an extinction event, the Bayesian credible interval represents the posterior probability that a species is extinct at a certain time given that it was not sampled, while the extinction confidence interval produced through the classical approach reflects the probability that a species was not sampled at a certain time because it was no longer present. We used the package "rcarbon" in R to create summed probability distributions for calibrated dates from extinct and extant fauna, and each distribution was normalized such that it integrates to one (Crema and Bevan, 2020). Note that all confidence/credible intervals for event estimation are sensitive to outliers (such as rare late occurrence data), and numerous historical accounts suggest that relict populations of extinct species may have survived until recent centuries (Godfrey, 1986; Flacourt, 1995; Burney and Ramilisonina., 1998; Nomenjanahary et al., 2021).

We follow the approach of Crowley and Godfrey (2013) to correct collagen $\delta^{13} \mathrm{C}$ values for the Suess effect (recent enrichment of atmospheric $\mathrm{CO}_{2}$ in ${ }^{13} \mathrm{C}$ due to the burning of fossil fuel). Specifically, we made modern and subfossil collagen $\delta^{13} \mathrm{C}$ values comparable by adding $0.004 \%$ to modern data for each year that passed from 1860 to $1965 \mathrm{AD}$ and $0.02 \%$ for each year that passed from 1965 to the time of death (if known) or sample collection (2019 most recently).

We used general linear models (GLMs, R package "glmulti," Calcagno and de Mazancourt, 2010) with corrected data to identify which variables drive variation in predator $\delta^{13} \mathrm{C}$ and $\delta^{15} \mathrm{~N}$ values (i.e., taxon, time, and location, Supplementary Tables 1, 2). Sites with data from both dogs and Cryptoprocta spp. (Figure 3, Andolonomby, Tsirave, and Ampasambazimba) are ideal for stable isotope comparisons. For example, Tsirave dog and C. ferox $\delta^{15} \mathrm{~N}$ values are comparable $(\operatorname{dog} n=4, \bar{x}=10.6 \%$, C. ferox $\mathrm{n}=3, \bar{x}=11.5 \%)$, yet Tsirave $\operatorname{dog} \delta^{13} \mathrm{C}$ values $(n=4$, $\bar{x}=-9.4 \%$ ) tend to be $\sim 10 \%$ higher than C. ferox $\delta^{13} \mathrm{C}$ values from this site $(n=3, \bar{x}=-19.6 \% 0)$. Unfortunately, most sites include data from less than five specimens. Given limited sitespecific sample sizes, we classified site location of dogs, C. ferox, and C. spelea according to coastal proximity and ecoregion. We defined coastal sites as those $\leq 10 \mathrm{~km}$ from the coast and inland sites as those $>10 \mathrm{~km}$ from the coast.

We simplified ecoregion data into two groups: SW Madagascar (including the spiny thicket and succulent woodland), and North-Central Madagascar (including the dry deciduous forest and central highlands). We combined data from the spiny thicket and succulent woodland ecoregions because they have similar climate and are both dominated by relatively xerophytic vegetation. Plants and animals from these two ecoregions have similar $\delta^{13} \mathrm{C}$ and $\delta^{15} \mathrm{~N}$ values, and are isotopically distinct from those of the relatively mesic central highlands and humid forest (Crowley et al., 2011). For similar reasons, we combine the single dog from the dry deciduous forest (PSUAMS 7663 from Lakato'ni Gavin in the far north) with the group from the central highlands. Note that only in our GLMs do we consider the limited stable isotope dataset for predators from North-Central Madagascar $(n=5)$. The rest of our analyses are focused exclusively on the SW. 
We also compared $\delta^{13} \mathrm{C}$ and $\delta^{15} \mathrm{~N}$ values for dogs from archeological and paleontological sites in inland SW Madagascar using t-tests. Sample sizes in these comparisons are small (archeological $n=5$, paleontological $n=6$ ), but neither $\delta^{13} \mathrm{C}$ nor $\delta^{15} \mathrm{~N}$ values within these groups violate the t-test assumptions of normality (Shapiro-Wilk $p \geq 0.06$ ) or equal variance (BrownForsythe $p \geq 0.23$ ).

Uneven sampling of individuals through space and time influences the observed variance in stable isotope values for dogs and Cryptoprocta spp. We used Stable Isotope Bayesian Ellipses in R (SIBER) to visually inspect the breadth of $\delta^{13} \mathrm{C}$ and $\delta^{15} \mathrm{~N}$ data from SW Madagascar (combining spiny thicket and succulent woodland) and also compare isotopic overlap between predator genera in a way that is unbiased by sample size (Jackson et al., 2011). We consider both standard ellipse areas (SEAs, which contain $\sim 40 \%$ of the data from each group) and ellipses that include $95 \%$ of the data from each group. Because our sample of $C$. spelea includes fewer than the recommended five specimens, we combined data from C. spelea and C. ferox. We feel this is reasonable because, within SW Madagascar, the two species have indistinguishable $\delta^{15} \mathrm{~N}$ values (Figure 6, C. spelea $n=3, m=14.0 \%$; C. ferox $\delta^{15} \mathrm{~N}$ value: $n=9, m=13.9 \%$, Mann-Whitney $U=12.00 ; p=0.85$ ), and $\delta^{13} \mathrm{C}$ values (C. spelea $n=3, m=-19.3 \%$; C. ferox $n=10, m=-18.6 \%$, MannWhitney $U=8.50, p=0.31$ ). Note that the similar stable isotope values of $C$. spelea and $C$. ferox do not exclude the possibility that these species preyed on different taxa that were isotopically similar. Before analysis with SIBER, we used Shapiro-Wilk tests to confirm that Cryptoprocta spp. and $\operatorname{dog} \delta^{13} \mathrm{C}$ and $\delta^{15} \mathrm{~N}$ values from SW Madagascar are normally distributed ( $p \geq 0.67)$.

Lastly, we plotted stable isotope data from predators and potential prey from SW Madagascar on the same graph to visually assess the potential for different patterns of predation. In this graph, we shifted predator $\delta^{13} \mathrm{C}$ and $\delta^{15} \mathrm{~N}$ values by -0.5 and $-3 \%$, respectively, to account for estimated offsets in stable isotope values between trophic levels (McCutchan et al., 2003), and we grouped prey species at different taxonomic levels (family and above). Large, species-specific lemur datasets are grouped according to family due to relatively similar isotopic niche spaces occupied by different species. We use higher level classification for other prey types (e.g., all birds grouped in Aves) due to limited sample sizes.

\section{RESULTS}

\section{Chronological Data}

Directly ${ }^{14} \mathrm{C}$-dated bones suggest a brief period of overlap between dogs and extinct giant lemurs in SW Madagascar and that dogs could have been present at kill sites during times that humans butchered extinct megafauna and an extant lemur (Propithecus verreauxi). Limited sample sizes prevent us from meaningfully considering differences in introduction and extinction timing in different ecoregions. However, our results suggest that dogs were widespread on Madagascar by $\sim 900$ calibrated years before present (cal BP, Figure 4). The oldest ${ }^{14} \mathrm{C}$-dated dog comes from the far northern archeological site of Lakato'ni Gavin (Figure 3, PSUAMS 7663, 1,035 $\pm 15{ }^{14} \mathrm{C}$ $\mathrm{BP}, 960-810 \mathrm{cal} \mathrm{BP})$ and is roughly contemporaneous with a dog from the archeological site of Andranosoa in the far south (PSUAMS 7623, 1,010 $\pm 15^{14} \mathrm{C} \mathrm{BP,} \mathrm{930-800} \mathrm{cal} \mathrm{BP).}$ The calibrated $95 \%$ age ranges of these two individuals overlap with those of five subfossil butchered extant lemurs (Propithecus verreauxi) from Taolambiby and with the three youngest ${ }^{14} \mathrm{C}$ dated extinct giant ruffed lemurs (Pachylemur insignis) from Tsirave (Figure 5). The youngest dated $P$. insignis from Tsirave (UCIAMS 167930, $940 \pm 20{ }^{14} \mathrm{C} \mathrm{BP}, 900-740 \mathrm{cal} \mathrm{BP}$ ) postdates the two earliest dogs by less than a century, and predates the oldest dog from Tsirave by ca. 80 years (CAMS 142889, $860 \pm 30$ ${ }^{14} \mathrm{C}$ BP, 790-670 cal BP).

Conservative estimates for SW Madagascar suggest the introduction of dogs (approximately 1,000 years ago) roughly coincided with the population collapse and possible extinction of Palaeopropithecus ingens, Archaeolemur majori, and P. insignis (between about 1,100 and $700 \mathrm{cal} \mathrm{BP;} \mathrm{Figure} \mathrm{5).} \mathrm{The} \mathrm{classical}$ $95 \%$ confidence interval for dog introduction $(1,120-870 \mathrm{cal} \mathrm{BP})$ also overlaps with the calibrated $95 \%$ age ranges for all 26 of the dated butchered bones in Figure 5. These include bones of extant $P$. verreauxi $(n=15)$, as well as extinct giant lemurs $[P$. insignis $(n=7)$ and $A$. majori $(n=1)$ ], elephant birds [Aepyornis maximus $(n=1)$ and Mullerornis modestus $(n=1)]$, and a pygmy hippo [Hippopotamus sp. $(n=1)]$.

\section{Stable Isotope Data}

Predator collagen $\delta^{13} \mathrm{C}$ and $\delta^{15} \mathrm{~N}$ values suggest dietary flexibility for dogs and some limited dietary overlap between Cryptoprocta spp. and dogs (Table 1 and Figure 6). All included predictor variables (i.e., taxon, ecoregion, coastal proximity, and time) contribute to the best fit GLMs (Supplementary Table 1) that explain variation in predator $\delta^{13} \mathrm{C}$ values (Model $1, n=37$, AIC $=170.84$ ) and $\delta^{15} \mathrm{~N}$ values (Model $2, n=36$, AIC $=142.04$ ). Model 1 suggests that both $C$. spelea and $C$. ferox had low $\delta^{13} \mathrm{C}$ values relative to dogs (Supplementary Table 2, $p=0.007$ and $p=0.02$, respectively). It also suggests that predator $\delta^{13} \mathrm{C}$ values in general tend to be relatively high in SW Madagascar $(p=0.0002)$ and that they also tend to be higher at coastal sites $(p=0.02)$. Overall, predator $\delta^{13} \mathrm{C}$ values may have decreased through time (Model $1 p=0.04$, Figure 7 ), primarily among the three C. spelea $(p=0.006)$. However, the model also suggests that combined predator $\delta^{13} \mathrm{C}$ increased through time both in SW Madagascar $(p=0.03)$ and at inland sites island-wide $(p=0.04)$. Model 2 suggests that $C$. ferox have high $\delta^{15} \mathrm{~N}$ values relative to dogs (Supplementary Table 2, $p=0.002$ ) and that C. ferox from coastal sites tend to have higher $\delta^{15} \mathrm{~N}$ values than those from inland sites $(p=0.02)$. It also suggests that both $C$. spelea and $C$. ferox $\delta^{15} \mathrm{~N}$ values increased through time $(p=0.05$ and $p=0.009$, respectively, Figure 7).

Standard ellipse areas (SEAs which encompass $40 \%$ of a group's data) are nearly twice as large for dogs $\left(9.6 \% 0^{2}\right)$ as they are for Cryptoprocta spp. in SW Madagascar (5.2\% ${ }^{2}$; Figure 6). While the SEAs do not overlap, ellipses that contain $~ 95 \%$ of the data from each group do overlap (Figure 6). The area of overlap between the $95 \%$ ellipses accounts for $\sim 34 \%$ of the isotopic 


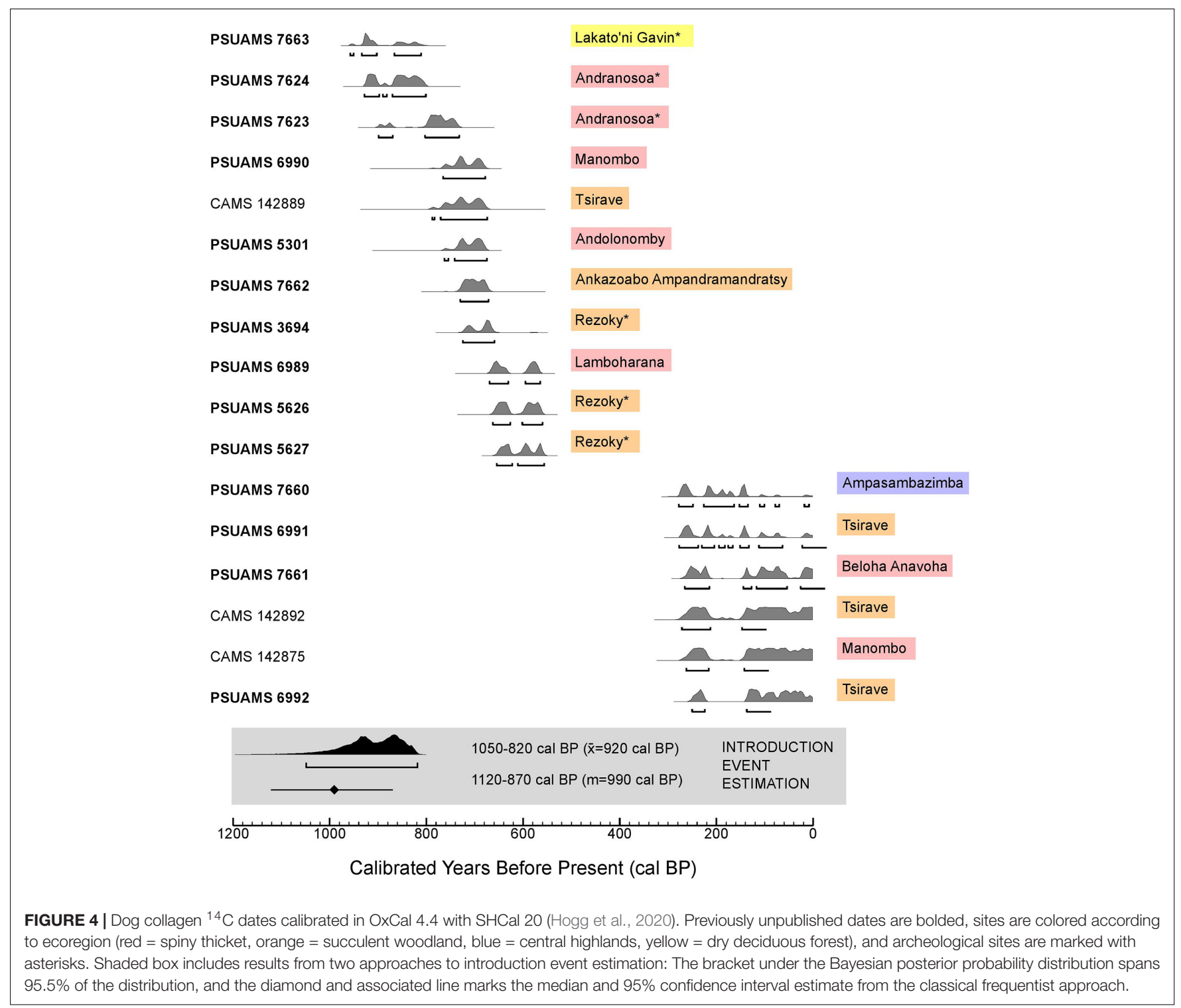

niche space of Cryptoprocta spp. but only $\sim 16 \%$ of the isotopic niche space of dogs. Samples of dog and Cryptoprocta spp. bones integrate different amounts of time and space, but these variables alone cannot explain the relatively large isotopic niche space occupied by dogs. Specifically, the range of dates for Cryptoprocta spp. is about twice as great as that for dogs (Figure 7). Also, although dogs from SW Madagascar come from a greater number of sites than Cryptoprocta spp. ( $n=8$ vs. $n=4)$, these sites represent similar geographical spread and include both inland and coastal sites (Figure 3 ).

Dogs generally tend to have higher $\delta^{13} \mathrm{C}$ values and lower $\delta^{15} \mathrm{~N}$ values than Cryptoprocta spp., but dogs from inland archeological sites in SW Madagascar (Rezoky \& Andranosoa) tend to have $\delta^{13} \mathrm{C}$ and $\delta^{15} \mathrm{~N}$ values that are relatively comparable with those of Cryptoprocta spp. (Figures 6, 7). Specifically, the mean ( \pm 1 SD) ${ }^{13} \mathrm{C}$ value for dogs from inland archeological sites in SW Madagascar $(n=5, \bar{x}=-14.9 \pm 1.4 \% 0)$ is significantly lower than the mean value for dogs from inland paleontological sites in this region $[n=6, \bar{x}=-11.1 \pm 3.3 \%, t(9)=2.42, p=0.04]$. However, limited sample sizes and limited contemporary samples from archeological and paleontological sites may confound this comparison, since $\operatorname{dog} \delta^{13} \mathrm{C}$ values across inland SW sites significantly increased during the past millennium $(n=11$, $\mathrm{r}_{\text {Spearman }}=0.60, p=0.05$, Figure 7). Additionally, the mean $\delta^{15} \mathrm{~N}$ value for dog collagen from archeological sites in this region $(n=5, \bar{x}=13.3 \pm 0.8 \% 0)$ is apparently, yet insignificantly, higher than the mean value for dogs from inland paleontological sites $[n=6, \bar{x}=11.9 \pm 2.4 \%, t(9)=1.26, p=0.24]$.

\section{DISCUSSION}

Brief overlap in directly dated introduced dogs and extinct megafauna means that we cannot reject the hypothesis that dogs could have helped humans hunt giant lemurs and possibly other megafauna at least $\sim 1,000$ years ago. Dogs have had diverse diets that are largely distinct from Cryptoprocta spp. diets and 


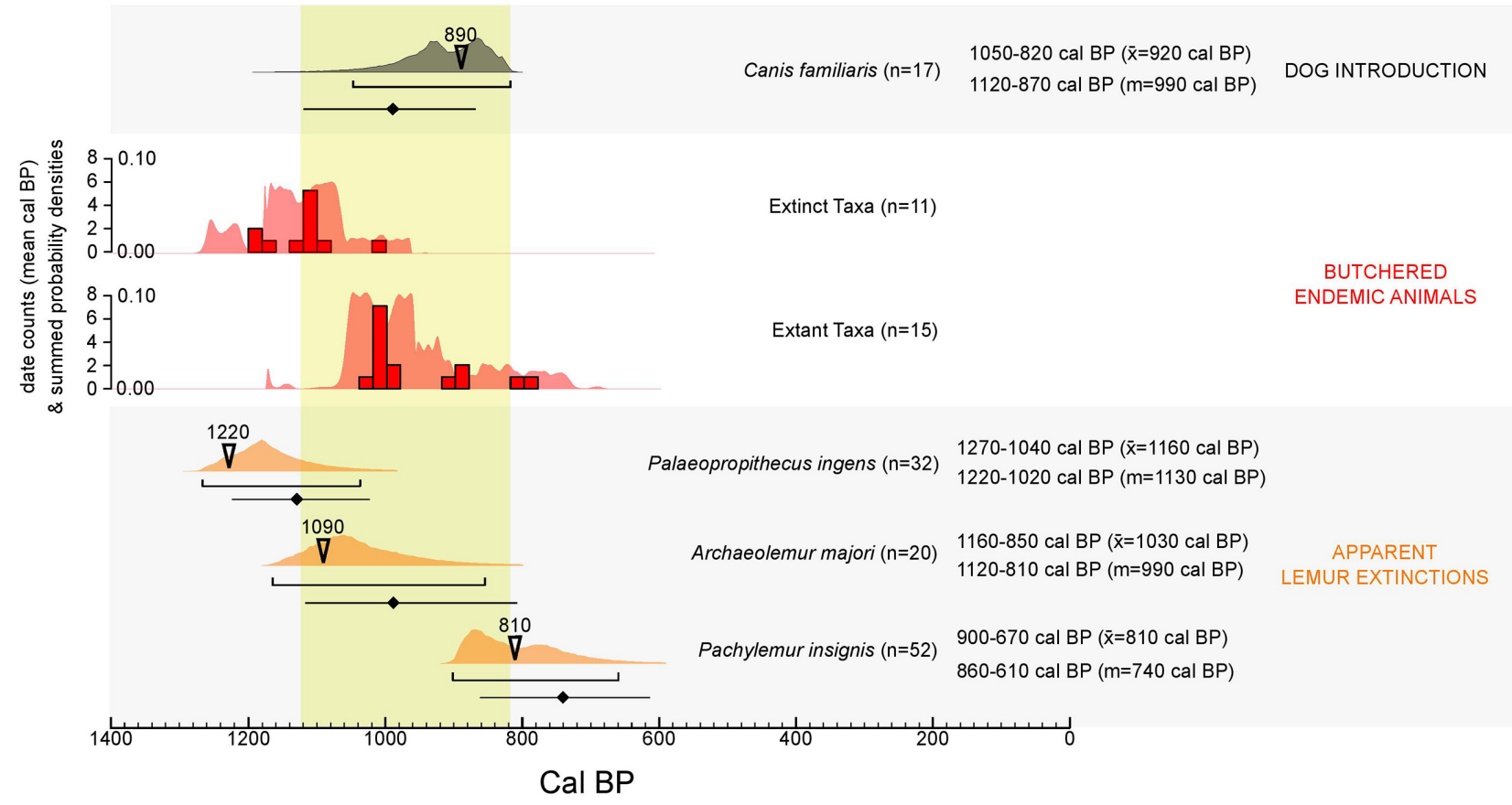

FIGURE 5 | Dog introduction event estimate compared to dates from butchered endemic animal bone and giant lemur extinction event estimation. Numbered arrowheads mark the mean calibrated date from the oldest recognized dog and youngest recognized giant lemur belonging to each taxon. See Figure $\mathbf{4}$ for explanation of confidence intervals for event estimation. Note that extinction confidence intervals consider only data from purified collagen. Dates from butchered animal bone are binned in 20-year intervals (saturated color) and are also displayed through summed probability distribution overlays (unsaturated color). Butchered extinct taxa represented in the histogram include Pachylemur insignis, Archaeolemur majori, Hippopotamus sp., Aepyornis maximus, and Mullerornis modestus. All of these taxa disappear from the subfossil record by $\sim 800$ cal BP (Crowley, 2010). Butchered extant taxa in the histogram include only P. verreauxi.

TABLE 1 | Descriptive statistics for island-wide Canis familiaris and Cryptoprocta spp. $\delta^{13} \mathrm{C}, \delta^{15} \mathrm{~N}$, and age data.

\begin{tabular}{cccccc}
\hline Taxon & $\mathbf{n}$ & $\overline{\boldsymbol{x}}$ & SD & Range & [min, max] \\
\hline$\delta^{13} \mathrm{C}(\%$, VPDB) & & & & & \\
$\quad$ Canis familiaris & 23 & -13.5 & 3.0 & 12.4 & {$[-20.4,-8.0]$} \\
$\begin{array}{c}\text { Cryptoprocta spp. } \\
14\end{array}$ & -18.9 & 1.1 & 4.0 & {$[-21.0,-17.0]$} \\
$\delta^{15} \mathrm{~N}(\%$, AIR) & & & & & \\
$\quad$ Canis familiaris & 23 & 12.3 & 1.8 & 6.6 & {$[9.1,15.7]$} \\
$\quad$ Cryptoprocta spp. & 13 & 13.6 & 1.6 & 5.1 & {$[11.2,16.3]$} \\
Age (mean cal BP) & & & & & \\
$\quad$ Canis familiaris & 23 & NA & NA & 959 & {$[890,-69]$} \\
Cryptoprocta spp. & 14 & NA & NA & 2,280 & {$[3,280,1,000]$}
\end{tabular}

Note that the range within each group includes both spatial and temporal variability (Figures 6, 7), and the $\delta^{13} \mathrm{C}$ values for the six modern dogs were corrected for the Suess Effect (following Crowley and Godfrey, 2013) so that they are comparable with subfossil collagen values.

include only minor inputs from forest-dwelling species, which is inconsistent with the hypothesis that dogs competed with Cryptoprocta spp. (Figures 6, 8). Nevertheless, dogs could have contributed to interference competition with endemic predators.

The introduction of dogs coincided with expanding human presence on Madagascar, which included the significant growth and movement of Malagasy populations (Pierron et al., 2017), the rise of the island's earliest urban center (Radimilahy, 1998), and the expansion of trade down the west coast of the island (Dewar and Wright, 1993; Boivin et al., 2013). Early trade connections between East Africa and Madagascar are consistent with the primarily African ancestry of Madagascar's dogs (Ardalan et al., 2015). However, given that the earliest directly ${ }^{14} \mathrm{C}$-dated dog (from Lakato'ni Gavin) slightly preceded the appearance of SE Asian rice and cotton in the region (Crowther et al., 2016), the potential for multiple past dog introductions should be considered through analysis of ancient DNA, if possible.

Early introduced dogs could have aided past human-led hunts of extant lemurs like $P$. verreauxi and megafauna that went extinct within the past millennium (Crowley, 2010; Hixon et al., submitted), but isotope data suggest that these kills did not form the bulk of dog diet (Figure 8). Most extinct megafauna browsed woody $\mathrm{C}_{3}$ vegetation (Crowley and Samonds, 2013; Godfrey and Crowley, 2016; Crowley et al., 2021; Hixon et al., submitted). A modern dog from Antsirabe does have an exceptionally low $\delta^{13} \mathrm{C}$ value $(-20.4 \% 0)$ and relatively high $\delta^{15} \mathrm{~N}$ value $(15.7 \% 0)$, which may indicate that it relied heavily on forest bushmeat. However, the wide range of $\operatorname{dog} \delta^{13} \mathrm{C}$ values likely reflects a continuum of reliance on agropastoralist-supplied foods (based on $\mathrm{C}_{4}$ or CAM plants), which is also observed in modern free-roaming dogs (Valenta et al., 2016). Consumption of scraps from butchered grazing livestock (e.g., zebu cattle) could have contributed to relatively high $\operatorname{dog} \delta^{13} \mathrm{C}$ values (Figure 8), particularly at archeological sites that include bones of dogs as 


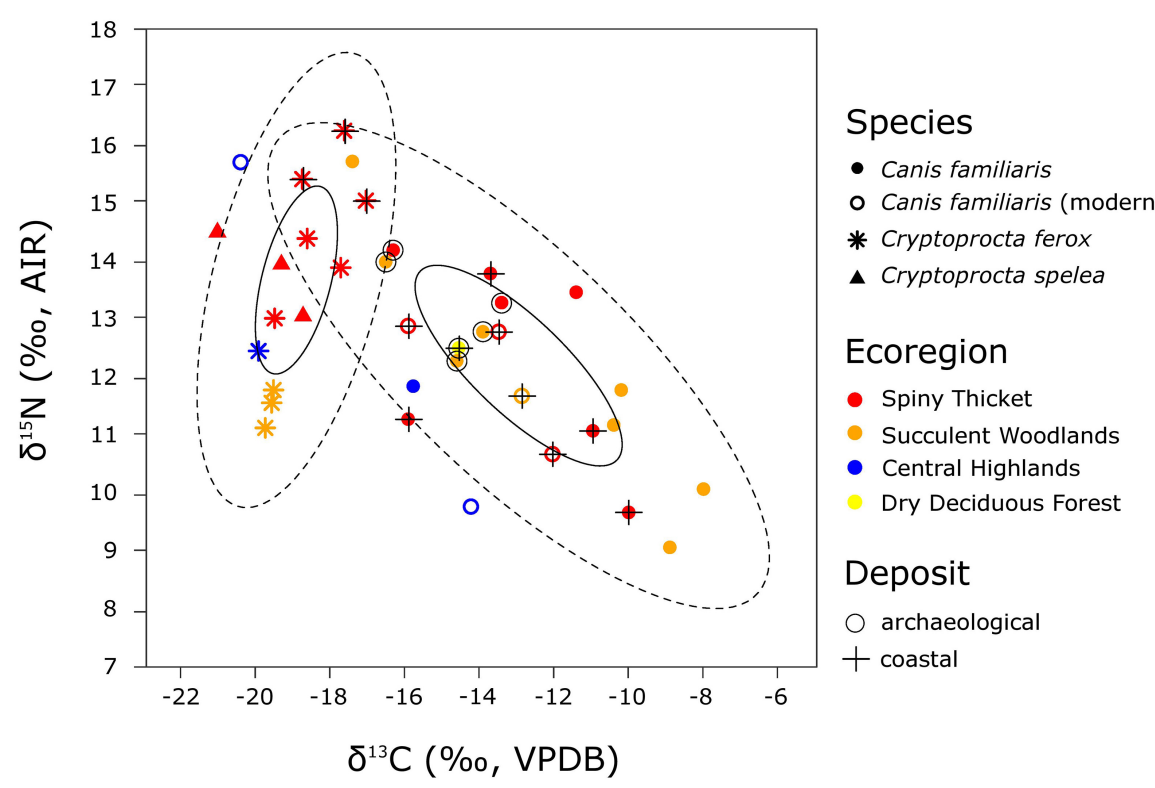

FIGURE 6 | Stable carbon and nitrogen isotope data for bone collagen from dogs (both modern and subfossil) and members of Cryptoprocta (all subfossil), with points colored according to ecoregion, shaped according to taxon, and marked according to deposit type $(n=36)$. For each genus, ellipses outline approximately $95 \%$ of the data (dashed) and $40 \%$ of the data (solid) from only the SW ecoregions (spiny thicket and succulent woodlands, Canis $n=19$, Cryptoprocta $n=12$ ). Island-wide, average calibrated dates for $C$. spelea specimens $(n=3)$ range from 3,280 to 1,760 cal BP, those for $C$. ferox $(n=10)$ range from 2,900 to 1,010 cal BP and those for dogs $(n=23)$ span from 890 cal BP to the present. The six modern dogs have $\delta^{13} \mathrm{C}$ values that are corrected for the Suess Effect (following Crowley and Godfrey, 2013) so that they are comparable with subfossil collagen values.

well as livestock (Vérin and Battistini, 1971; Rasamuel, 1984; Hixon et al., submitted). However, rather counterintuitively, dogs from inland archeological sites in the arid SW tend to have lower $\delta^{13} \mathrm{C}$ values than those from inland paleontological sites where they were less likely to be associated with pastoralists. The relatively low $\delta^{13} \mathrm{C}$ values of dogs from archeological sites could be explained by reliance on provisioned scraps from ovicaprids that browsed on a wide range of vegetation (Hixon et al., submitted) or from endemic, forest-dwelling game hunted by humans in forests dominated by $\mathrm{C}_{3}$ plants (Figure 8; Decary, 1939). Archeological bone deposits in SW Madagascar tend to be highly fragmentary and may include traces of scavenging (Vérin and Battistini, 1971; Douglass et al., 2018). There are abundant marks of mammalian carnivoran predation and scavenging on the bones of extinct giant lemurs at paleontological sites (Meador et al., 2019, also at Taolambiby, Clark, pers. comm.), and the possibility that both Cryptoprocta spp. and dogs contributed to these patterns of gnaw marks on relatively recent bones cannot be excluded.

Past exploitation competition between dogs and Cryptoprocta spp. seems unlikely given that isotope data suggest ancient Cryptoprocta spp. consumed mostly forest dwelling animals (e.g., lemurs), while dogs have relied more heavily on prey from relatively open habitats (e.g., scraps from the food of agropastoral communities). Dogs may be replacing endemic predators around human communities today (Farris et al., 2016), but the distinct diets of dogs and Cryptoprocta spp. suggest that dogs are not fulfilling the ecological role of Cryptoprocta spp. In particular, the distinct isotopic niches of dogs and Cryptoprocta spp. suggest that any past antagonistic relationship between these predators did not follow from predation or competition for shared prey. Instead, dogs could have antagonized Cryptoprocta spp. through exclusion competition by chasing shared prey, creating a landscape of fear, and thus contributing to habitat fragmentation (Laundré et al., 2010). The directly ${ }^{14} \mathrm{C}$-dated subfossil record for $C$. spelea is sparse $(n=3)$, yet recent accounts of what may be $C$. spelea still living in the far north of Madagascar (Nomenjanahary et al., 2021) suggest that there may be a history of interaction between dogs and C. spelea. Dogs may occasionally prey on C. ferox (Valenta et al., 2016), yet comparable $\delta^{15} \mathrm{~N}$ values for dogs and C. ferox suggest that dogs have not routinely consumed endemic predators, such as C. ferox, or other introduced predators, such as cats, during the past millennium (Figure 8). The observation that dogs rarely prey on cats is consistent with the modern observation that both exotic predators are often simultaneously abundant (Farris et al., 2014).

Although there was limited dietary overlap between C. ferox and dogs $\sim 1,000$ years ago, this may have expanded during the past millennium as $C$. ferox came into more frequent contact with human modified landscapes that tend to have higher plant and animal $\delta^{13} \mathrm{C}$ values. Palynological and geochemical records from much of Madagascar document the expansion of grasslands favored by livestock and dogs during the past millennium (Burney, 1987; Crowley and Samonds, 2013; Burns et al., 2016; Virah-Sawmy et al., 2016; Domic et al., 2021). Future stable isotope work with modern and subfossil C. ferox individuals that span the past millennium can test this possibility. C. ferox continues to hunt in shrinking forest fragments but may partly 


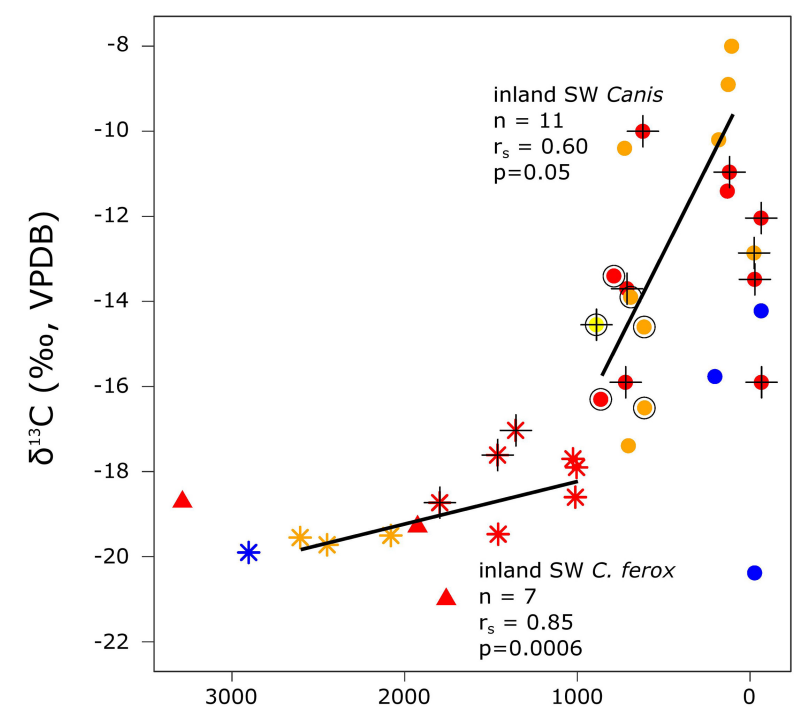

Calibrated Years Before Present

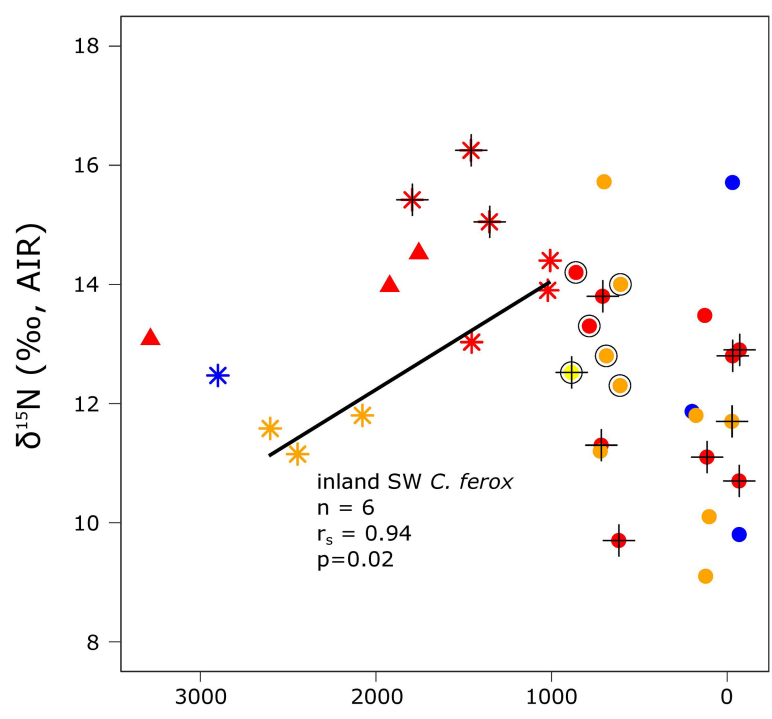

Calibrated Years Before Present

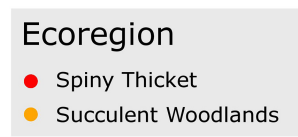

- Central Highlands

Dry Deciduous Forest

\section{Species}

* Cryptoprocta ferox

- Cryptoprocta spelea

\section{Deposit}

archaeological + coastal

FIGURE 7 | Temporal trends in stable carbon and nitrogen isotope data for bone collagen from dogs (both modern and subfossil) and members of Cryptoprocta (all subfossil), with points colored according to ecoregion, shaped according to taxon, and marked according to deposit type $\left(\delta^{13} \mathrm{C} n=37\right.$, $\left.\delta^{15} \mathrm{~N} n=36\right)$. The six modern dogs have $\delta^{13} \mathrm{C}$ values that are corrected for the Suess Effect (following Crowley and Godfrey, 2013) so that they are comparable with subfossil collagen values. Trend lines illustrate the only significant temporal trends when controlling for region and coastal proximity: In inland SW Madagascar (including both spiny thicket and succulent woodlands), dog and C. ferox $\delta^{13} \mathrm{C}$ values and $\mathrm{C}$. ferox $\delta^{15} \mathrm{~N}$ values significantly increased through time, yet these trends could be explained by uneven sampling across archeological versus paleontological deposits in the case of dogs or by uneven sampling between the spiny thicket and succulent woodlands in the case of C. ferox.

exploit the expanding anthropogenic niche, as documented in other taxa such as vervet monkeys (Chlorocebus pygerythrus) on mainland Africa (e.g., Loudon et al., 2014). Cryptoprocta ferox is known to navigate deforested areas (Wyza et al., 2020), and there are numerous recent accounts of $C$. ferox raiding poultry and controlling introduced rat populations (Merson et al., 2019b).

Ongoing efforts try to control dog populations, yet dogs are only part of the picture. A growing body of directly ${ }^{14} \mathrm{C}$-dated specimens of introduced animals suggests that dogs became established on Madagascar at approximately the same time as introduced herbivores (zebu cattle and ovicaprids, Hixon et al., submitted) and at possibly the same time as cats (Sauther et al., 2020). Genetic data from Madagascar's modern cats indicate that their ancestors colonized the island from the Arabian Sea region within the past millennium (Sauther et al., 2020). Similar to dogs, cats are a successful invasive predator on numerous islands (Medina et al., 2011; Nogales et al., 2013). However, unlike dogs, cats may be a closer functional replacement for Cryptoprocta spp. since they also climb trees. Cats successfully prey on a large variety of endemic species on Madagascar (Brockman et al., 2008; Merson, 2017) and are difficult for endemic predators to avoid (Gerber et al., 2012). Existing $\delta^{13} \mathrm{C}$ data from four cats in SW Madagascar (Figure 8) could suggest that they consumed different prey than Cryptoprocta spp., but the available sample size is quite small. Though cats are well-represented in archeological deposits of $\sim 1,000$ years ago on the island of Mayotte ( $330 \mathrm{~km}$ NW of Madagascar), subfossil felid remains are unfortunately very scarce in Madagascar's paleontological and archeological deposits (Petit, 1933; Chanudet, 1975). The analysis of additional cat remains would better clarify when cats arrived on Madagascar and how their diets compared to those of other predators.

Madagascar's ecosystems continue to face new species introductions (e.g., Asian toads; Kolby, 2014) and shifts in land use (e.g., cash cropping; Réau, 2002) that threaten endemic biodiversity. The suite of past animal introductions that included dogs and livestock coincided with a pulse of megafaunal extinction and constituted an early turning point in Malagasy socio-ecological history. This situation is analogous to the colonization of Remote Oceania by people with a "transported landscape" that included dogs, pigs, rats, and chickens (Anderson, 2009). During the brief co-occurrence of dogs, introduced livestock, and endemic megafauna on Madagascar, pastoralists both relied on their livestock and opportunistically hunted endemic animals (Vérin and Battistini, 1971; Rasamuel, 1984). Introduced animals compounded negative impacts of humans on endemic fauna. Livestock provided a reliable food supply for growing human 


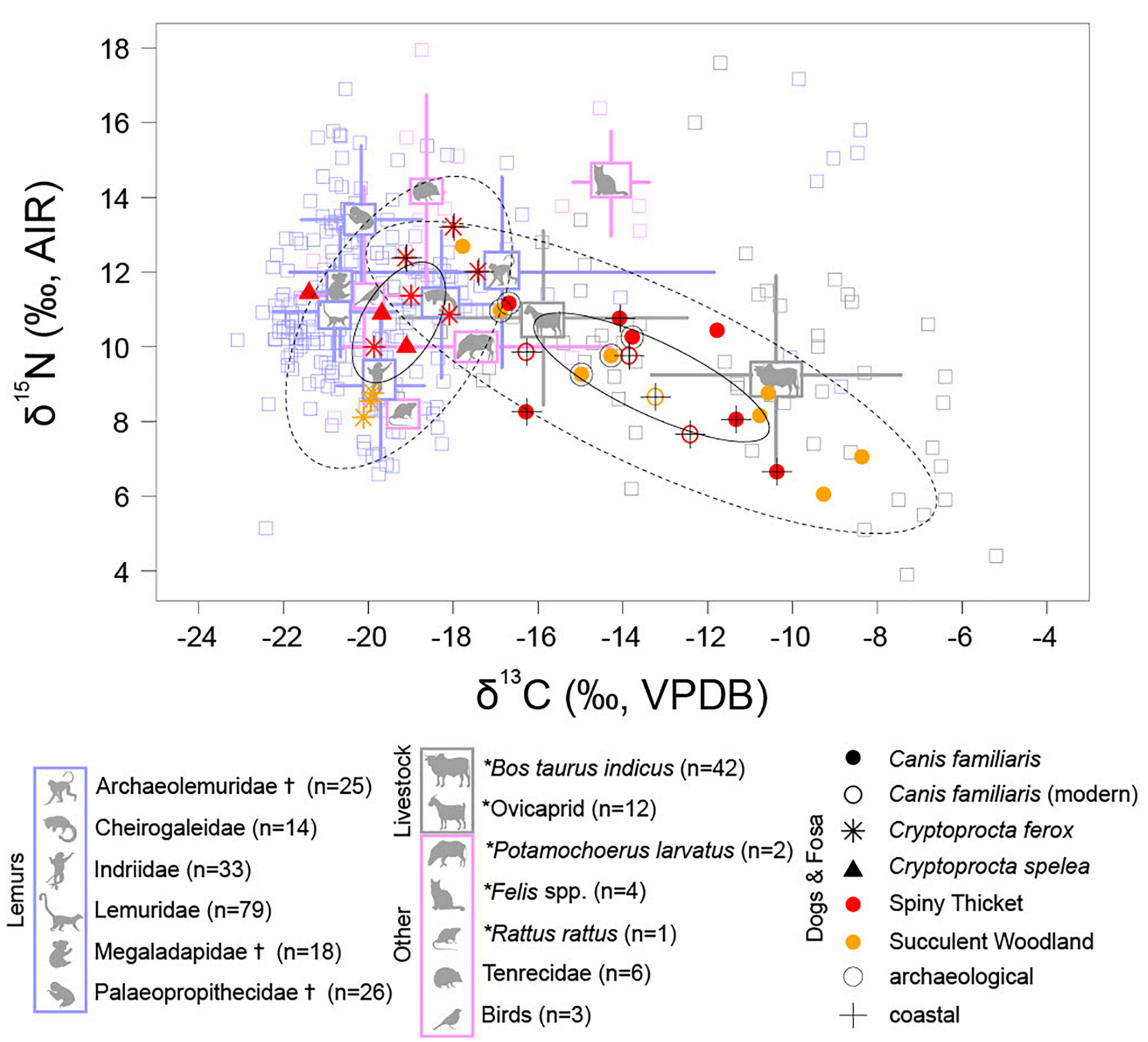

FIGURE 8 | Stable carbon and nitrogen isotope data for bone collagen from dogs (both modern and subfossil) and members of Cryptoprocta (all subfossil) collected in SW Madagascar, with points colored according to ecoregion, shaped according to taxon, and marked according to deposit type $(n=36$, see Figure $\mathbf{5}$ explanation of ellipses fitted to dog and Cryptoprocta spp. data). Stable isotope data from the bone collagen of lemurs, livestock, and other animals collected in SW Madagascar are plotted for reference, with icons marking means and lines marking standard deviations in $\delta^{13} \mathrm{C}$ and $\delta^{15} \mathrm{~N}$ values. Note that extinct families of giant lemurs are marked with ( $\dagger$ ), introduced taxa are marked with (*), and modern individuals (including six modern dogs) have $\delta^{13} \mathrm{C}$ values that are corrected for the Suess Effect (following Crowley and Godfrey, 2013) so that they are comparable with subfossil collagen values. Also note that dog and Cryptoprocta spp. $\delta^{13} \mathrm{C}$ and $\delta^{15} \mathrm{~N}$ values are shifted by -0.5 and $-3 \%$, respectively, to account for estimated offsets in stable isotope values between trophic levels (McCutchan et al., 2003). Thus, the dog and Cryptoprocta spp. points approximate the isotopic composition of their diet.

populations (Pierron et al., 2017), and we have shown here that dogs could have aided human-led hunts and contributed to habitat fragmentation during the past millennium. However, forest-dwelling endemic animals contributed relatively little to dog diet. The colonization of Madagascar by pastoralists and introduced predators likely had dramatic environmental consequences and formed what can be considered the first step in the biotic homogenization of the island.

\section{DATA AVAILABILITY STATEMENT}

The original contributions presented in the study are included in the article/Supplementary Material, further inquiries can be directed to the corresponding author.

\section{ETHICS STATEMENT}

Ethical review and approval was not required for the animal study because the work focuses on ancient vertebrates.

\section{AUTHOR CONTRIBUTIONS}

SWH, DK, KD, BC, LG, LR, and HW designed the research. SWH, KD, LE, and BC performed the analyses. SWH, KD, LG, BC, LR, GC, AA, SH, and HW aided sample collection and identification. SWH and DK wrote the manuscript. All authors edited the manuscript.

\section{FUNDING}

This research was supported by the National Science Foundation Grants GRFP-2015213455 to SWH, Archaeology DDRI-1838393 to DK and SWH, BCS-1750598 to LG, BCS-1749676 to BC, AGS-1702891 to Stephen Burns with support for LG, and by additional funding from Sigma Xi, the American Philosophical Society, Society for Archeological Science, PSU Energy and Environmental Sustainability Laboratories, PSU Africana Research Center, and PSU Anthropology Department. General laboratory support was provided by the NSF Archaeometry Program (BCS-1460367 to DK) and the Pennsylvania State University (DK). 


\section{ACKNOWLEDGMENTS}

We thank G. Billet and C. Argot for help with sampling bones from existing collections, S. Burns for partial support of LG collections research at the Université d'Antananarivo, the crew of the Morombe Archeological Project, Prof. Manjakahery, and D. Damy of the University of Toliara's Centre de Documentation et de Recherche sur l'Art et les Traditions Orales à Madagascar (CeDRATOM) for their assistance during field collection, B. Culleton and

\section{REFERENCES}

Anderson, A. (2009). The rat and the octopus: Initial human colonization and the prehistoric introduction of domestic animals to Remote Oceania. Biol. Invas. 11, 1503-1519. doi: 10.1007/s10530-008-9403-2

Anderson, A., Clark, G., Haberle, S., Higham, T., Nowak-Kemp, M., Prendergast, A., et al. (2018). New evidence of megafaunal bone damage indicates late colonization of Madagascar. PloS One 13:e0204368. doi: 10.1371/journal.pone. 0204368

Anonymous (2003). "Madagascar rural and environment sector review," in Main Report. World Bank.

Ardalan, A., Oskarsson, M. C., Van Asch, B., Rabakonandriania, E., and Savolainen, P. (2015). African origin for Madagascan dogs revealed by mtDNA analysis. R. Soc. Open Sci. 2:140552. doi: 10.1098/rsos.140552

Austin, A. T., and Vitousek, P. (1998). Nutrient dynamics on a precipitation gradient in Hawai'i. Oecologia 113, 519-529. doi: 10.1007/s004420050405

Barcala, O. (2009). Invasive stray and feral dogs limit fosa (Cryptoprocta ferox) populations in Ankarafantsika National Park, Madagascar. (M. Sc. thesis). Durham: Duke University.

Beaumont, W., Beverly, R., Southon, J., and Taylor, R. (2010). Bone preparation at the KCCAMS laboratory. Nuclear Instru. Methods Phys. Res. Sec.B Beam Interac. Mat. Atoms 268, 906-909. doi: 10.1016/j.nimb.2009.10.061

Blench, R. (2008). The austronesians in Madagascar and their interaction with the bantu of the east african coast: surveying the linguistic evidence for domestic and translocated animals. Stud. Philippine Lang. Cultures 18, 18-43.

Boivin, N., Crowther, A., Helm, R., and Fuller, D. Q. (2013). East Africa and Madagascar in the Indian ocean world. J. World Prehistory 26, 213-281. doi: 10.1007/s10963-013-9067-4

Bradshaw, C., Cooper, A., Turney, C., and Brook, B. (2012). Robust estimates of extinction time in the geological record. Quat. Sci. Rev. 33, 14-19. doi: 10.1016/j.quascirev.2011.11.021

Brock, F., Higham, T., and Ramsey, C. B. (2010). Pre-screening techniques for identification of samples suitable for radiocarbon dating of poorly preserved bones. J. Archaeol. Sci. 37, 855-865. doi: 10.1016/j.jas.2009.11.015

Brockman, D. K., Godfrey, L. R., Dollar, L. J., and Ratsirarson, J. (2008). Evidence of invasive Felis silvestris predation on Propithecus verreauxi at Beza Mahafaly special reserve, Madagascar. Int. J. Primatol. 29, 135-152. doi: 10.1007/s10764007-9145-5

Buck, C. E., and Bard, E. (2007). A calendar chronology for Pleistocene mammoth and horse extinction in North America based on Bayesian radiocarbon calibration. Quat. Sci. Rev. 26, 2031-2035. doi: 10.1016/j.quascirev.2007.06.013

Burney, D. A. (1987). Late holocene vegetational change in central Madagascar. Quat. Res. 28, 130-143. doi: 10.1016/0033-5894(87)90038-x

Burney, D. A., Burney, L. P., Godfrey, L. R., Jungers, W. L., Goodman, S. M., Wright, H. T., et al. (2004). A chronology for late prehistoric Madagascar. J. Hum. Evol. 47, 25-63. doi: 10.1016/j.jhevol.2004.05.005

Burney, D. A., Hume, J. P., Randalana, R., Andrianaivoarivelo, R. A., Griffiths, O., Middleton, G. J., et al. (2020). Rock art from andriamamelo cave in the beanka protected area of western Madagascar. J. Island Coastal Archaeol. 2020, 1-24. doi: 10.1080/15564894.2020.1749735

Burney, D. A., and Ramilisonina. (1998). The Kilopilopitsofy, Kidoky, and Bokyboky: Accounts of strange animals from Belo-sur-mer, Madagascar, and the Megafaunal "Extinction Window". Am. Anthropol. 100, 957-966. doi: 10. 1525/aa.1998.100.4.957
J. Southon for assistance during laboratory analysis, and two reviewers (including Z. Farris) for their thoughtful comments on the manuscript.

\section{SUPPLEMENTARY MATERIAL}

The Supplementary Material for this article can be found online at: https://www.frontiersin.org/articles/10.3389/fevo.2021. 689559/full\#supplementary-material

Burns, S. J., Godfrey, L. R., Faina, P., McGee, D., Hardt, B., Ranivoharimanana, L., et al. (2016). Rapid human-induced landscape transformation in Madagascar at the end of the first millennium of the Common Era. Quat. Sci. Rev. 134, 92-99. doi: 10.1016/j.quascirev.2016.01.007

Butler, J., Du Toit, J., and Bingham, J. (2004). Free-ranging domestic dogs (Canis familiaris) as predators and prey in rural Zimbabwe: threats of competition and disease to large wild carnivores. Biol. Conserv. 115, 369-378. doi: 10.1016/ s0006-3207(03)00152-6

Calcagno, V., and de Mazancourt, C. (2010). glmulti: an R package for easy automated model selection with (generalized) linear models. J. Stat. Software $34,1-29$.

Chanudet, C. (1975). Conditions géographiques et archéologiques de la disparition des subfossiles à Madagascar. Mémoire de Maîtrise. Brest: Université de Bretagne Occidentale.

Cleland, C. E. (2001). Historical science, experimental science, and the scientific method. Geology 29, 987-990. doi: 10.1130/0091-7613(2001)029<0987:hsesat> 2.0.co;2

Crawford, K., Mcdonald, R. A., and Bearhop, S. (2008). Applications of stable isotope techniques to the ecology of mammals. Mammal. Rev. 38, 87-107. doi: 10.1111/j.1365-2907.2008.00120.x

Crema, E. R., and Bevan, A. (2020). Inference from large sets of radiocarbon dates: software and methods. Radiocarbon 63, 23-39. doi: 10.1017/rdc.2020.95

Crowley, B. E. (2010). A refined chronology of prehistoric Madagascar and the demise of the megafauna. Quat. Sci. Rev. 29, 2591-2603. doi: 10.1016/j. quascirev.2010.06.030

Crowley, B. E., and Godfrey, L. R. (2013). Why all those spines?: Anachronistic defenses in the Didiereoideae against now extinct lemurs. South Afr. J. Sci. 109, 1-7. doi: 10.1590/sajs.2013/1346

Crowley, B. E., Godfrey, L. R., Bankoff, R. J., Perry, G. H., Culleton, B. J., Kennett, D. J., et al. (2017). Island-wide aridity did not trigger recent megafaunal extinctions in Madagascar. Ecography 40, 901-912. doi: 10.1111/ecog. 02376

Crowley, B. E., Godfrey, L. R., Hansford, J. P., and Samonds, K. E. (2021). Seeing the forest for the trees - and the grasses: Revisiting the evidence for grazermaintained grasslands in Madagascar's Central Highlands. Proc. R. Soc. Lond. B. 288:1785. doi: $10.1098 / \mathrm{rspb} .2020 .1785$

Crowley, B. E., McGoogan, K. C., and Lehman, S. M. (2012). Edge effects on foliar stable isotope values in a Madagascan tropical dry forest. PloS One 7:e44538. doi: 10.1371/journal.pone.0044538

Crowley, B. E., Rasoazanabary, E., and Godfrey, L. R. (2014). Stable isotopes complement focal individual observations and confirm dietary variability in reddish-gray mouse lemurs (Microcebus griseorufus) from southwestern Madagascar. Am. J. Phys. Anthropol. 155, 77-90. doi: 10.1002/ajpa.22555

Crowley, B. E., and Samonds, K. E. (2013). Stable carbon isotope values confirm a recent increase in grasslands in northwestern Madagascar. Holocene 23, 1066-1073. doi: 10.1177/0959683613484675

Crowley, B. E., Thorén, S., Rasoazanabary, E., Vogel, E. R., Barrett, M. A., Zohdy, S., et al. (2011). Explaining geographical variation in the isotope composition of mouse lemurs (Microcebus). J. Biogeogr. 38, 2106-2121. doi: 10.1111/j.13652699.2011.02551.x

Crowther, A., Lucas, L., Helm, R., Horton, M., Shipton, C., Wright, H. T., et al. (2016). Ancient crops provide first archaeological signature of the westward Austronesian expansion. Proc. Nat. Acad. Sci. 113, 6635-6640. doi: 10.1073/ pnas. 1522714113 
Cupples, J. B., Crowther, M. S., Story, G., and Letnic, M. (2011). Dietary overlap and prey selectivity among sympatric carnivores: could dingoes suppress foxes through competition for prey? J. Mammal. 92, 590-600. doi: 10.1644/10mamm-a-164.1

Decary, R. (1939). La chasse et le piégeage chez les indigènes de Madagascar. J. des Africanistes 9, 3-41. doi: 10.3406/jafr.1939.2468

DeNiro, M. J. (1985). Postmortem preservation and alteration of in vivo bone collagen isotope ratios in relation to palaeodietary reconstruction. Nature 317, 806-809. doi: 10.1038/317806a0

Dewar, R. E. (1997). "Were people responsible for the extinction of Madagascar's subfossils, and how will we ever know," in . Natural change and human impact in Madagascar, eds S. M. Goodman and B. P. Patterson (Washington, DC: Smithsonian Institution Press), 364-377.

Dewar, R. E., Radimilahy, C., Wright, H. T., Jacobs, Z., Kelly, G. O., and Berna, F. (2013). Stone tools and foraging in northern Madagascar challenge Holocene extinction models. Proc. Natl. Acad. Sci. 110, 12583-12588. doi: 10.1073/pnas. 1306100110

Dewar, R. E., and Wright, H. T. (1993). The culture history of Madagascar. J. World Prehistory 7, 417-466. doi: 10.1007/bf00997802

Dollar, L., Ganzhorn, J. U., and Goodman, S. M. (2007). "Primates and other prey in the seasonally variable diet of Cryptoprocta ferox in the dry deciduous forest of western Madagascar," in Primate anti-predator strategies. Berlin: Springer, $63-76$.

Domic, A. I., Hixon, S. W., Velez, M. I., Ivory, S. J., Douglass, K. G., Brenner, M., et al. (2021). Influence of late Holocene climate change, megafaunal extinction, and human occupation on terrestrial and aquatic ecosystems in SW Madagascar. Front. Ecol. Evol.

Douglass, K., Antonites, A. R., Morales, E. M. Q., Grealy, A., Bunce, M., Bruwer, C., et al. (2018). Multi-analytical approach to zooarchaeological assemblages elucidates Late Holocene coastal lifeways in southwest Madagascar. Quat. Int. 471, 111-131. doi: 10.1016/j.quaint.2017.09.019

Douglass, K., Hixon, S., Wright, H. T., Godfrey, L. R., Crowley, B. E., Manjakahery, B., et al. (2019). A critical review of radiocarbon dates clarifies the human settlement of Madagascar. Quat. Sci. Rev. 221:105878. doi: 10.1016/j.quascirev. 2019.105878

Faina, P., Burns, S. J., Godfrey, L. R., Crowley, B. E., Scroxton, N., McGee, D., et al. (2021). Comparing the paleoclimates of northwestern and southwestern Madagascar during the late Holocene: implications for the role of climate in megafaunal extinction. Malagasy Nat. 15.

Farquhar, G. D., Ehleringer, J. R., and Hubick, K. T. (1989). Carbon isotope discrimination and photosynthesis. Ann. Rev. Plant Biol. 40, 503-537.

Farris, Z., Gerber, B., Karpanty, S., Murphy, A., Andrianjakarivelo, V., Ratelolahy, F., et al. (2015). When carnivores roam: temporal patterns and overlap among Madagascar's native and exotic carnivores. J. Zool. 296, 45-57. doi: 10.1111/jzo. 12216

Farris, Z., Kelly, M., Karpanty, S., and Ratelolahy, F. (2016). Patterns of spatial cooccurrence among native and exotic carnivores in north-eastern Madagascar. Anim. Conserv. 19, 189-198. doi: 10.1111/acv.12233

Farris, Z. J., Karpanty, S. M., Ratelolahy, F., and Kelly, M. J. (2014). Predatorprimate distribution, activity, and co-occurrence in relation to habitat and human activity across fragmented and contiguous forests in northeastern Madagascar. Int. J. Primatol. 35, 859-880. doi: 10.1007/s10764-014-9786-0

Farris, Z. J., Kelly, M. J., Karpanty, S., Murphy, A., Ratelolahy, F., Andrianjakarivelo, V., et al. (2017). The times they are a changin': Multiyear surveys reveal exotics replace native carnivores at a Madagascar rainforest site. Biol. Conserv. 206, 320-328. doi: 10.1016/j.biocon.2016.10.025

Fernandes, D. M., Sirak, K. A., Ringbauer, H., Sedig, J., Rohland, N., Cheronet, O., et al. (2021). A genetic history of the pre-contact Caribbean. Nature 590, 103-110.

Flacourt, E. D. (1995). Histoire de la grande isle Madagascar. Paris: Karthala/INALCO.

France, C. A., Giaccai, J. A., and Cano, N. (2011). The effects of PVAc treatment and organic solvent removal on $\delta 13 \mathrm{C}, \delta 15 \mathrm{~N}$, and $\delta 18 \mathrm{O}$ values of collagen and hydroxyapatite in a modern bone. J. Archaeol. Sci. 38, 3387-3393. doi: 10.1016/j.jas.2011.07.024

Garcia, G., and Goodman, S. M. (2003). Hunting of protected animals in the Parc National d'Ankarafantsika, north-western Madagascar. Oryx 37, $115-118$.
Gardner, C. J., and Davies, Z. G. (2014). Rural bushmeat consumption within multiple-use protected areas: qualitative evidence from southwest Madagascar. Hum. Ecol. 42, 21-34. doi: 10.1007/s10745-013-9629-1

Gerber, B. D., Karpanty, S. M., and Randrianantenaina, J. (2012). Activity patterns of carnivores in the rain forests of Madagascar: implications for species coexistence. J. Mammal. 93, 667-676. doi: 10.1644/11-mamm-a-265.1

Godfrey, L., and Crowley, B. (2016). Madagascar's ephemeral palaeo-grazer guild: who ate the ancient C4 grasses? Proc. R. Soc. B 283:20160360. doi: 10.1098/rspb. 2016.0360

Godfrey, L. R. (1986). The tale of the tsy-aomby-aomby. Sciences 26, 48-51. doi: 10.1002/j.2326-1951.1986.tb02826.x

Godfrey, L. R., and Douglass, K. G. (2021). "New insights into the relationship between human-ecological pressure and the vertebrate extinctions," in The New Natural History of Madagascar, ed. S. M. Goodman (Princeton: Princeton University Press).

Godfrey, L. R., Scroxton, N., Crowley, B. E., Burns, S. J., Sutherland, M. R., Pérez, V. R., et al. (2019). A new interpretation of Madagascar's megafaunal decline: The "Subsistence Shift Hypothesis". J. Hum. Evol. 130, 126-140. doi: 10.1016/j. jhevol.2019.03.002

Goodman, S., Langrand, O., and Rasolonandrasana, B. (1997). The food habits of Cryptoprocta ferox in the high mountain zone of the Andringitra Massif, Madagascar (Carnivora, Viverridae). Mammalia 61, 185-192.

Goodman, S. M., Rasoloarison, R. M., and Ganzhorn, J. U. (2004). On the specific identification of subfossil Cryptoprocta (Mammalia, Carnivora) from Madagascar. Zoosyst. PARIS 26, 129-143.

Guiry, E. J., Szpak, P., and Richards, M. P. (2016). Effects of lipid extraction and ultrafiltration on stable carbon and nitrogen isotopic compositions of fish bone collagen. Rapid Commun. Mass Spectr. 30, 1591-1600. doi: 10.1002/rcm. 7590

Hansford, J., Wright, P. C., Rasoamiaramanana, A., Perez, V. R., Godfrey, L. R., Errickson, D., et al. (2018). Early Holocene human presence in Madagascar evidenced by exploitation of avian megafauna. Sci. Adv. 4:eaat6925. doi: 10. 1126/sciadv.aat6925

Hawkins, C. E., and Racey, P. A. (2008). Food habits of an endangered carnivore, Cryptoprocta ferox, in the dry deciduous forests of western Madagascar. J. Mammal. 89, 64-74. doi: 10.1644/06-mamm-a-366.1

Heaton, T. H. (1987). The $15 \mathrm{~N} / 14 \mathrm{~N}$ ratios of plants in South Africa and Namibia: relationship to climate and coastal/saline environments. Oecologia 74, 236-246. doi: 10.1007/bf00379365

Heck, L., Crowley, B., Thorén, S., and Radespiel, U. (2016). "14 Determinants of isotopic variation in two sympatric mouse lemur species from northwestern Madagascar," in The Dwarf and Mouse Lemurs of Madagascar: Biology, Behavior and Conservation Biogeography of the Cheirogaleidae, Vol. 73, eds S. M. Lehman, U. Radespiel, and E. Zimmermann (Cambridge, U.K: Cambridge University Press), 281-304. doi: 10.1017/cbo9781139871822.015

Higham, T. F., Jacobi, R. M., and Ramsey, C. B. (2006). AMS radiocarbon dating of ancient bone using ultrafiltration. Radiocarbon 48, 179-195. doi: 10.1017/ s0033822200066388

Hixon, S. W., Elliott Smith, E. A., Crowley, B. E., Perry, G. H., Randrianasy, J., Ranaivoarisoa, J. F., et al. (2018). Nitrogen isotope $\left(\delta^{15} \mathrm{~N}\right)$ patterns for amino acids in lemur bones are inconsistent with aridity driving megafaunal extinction in south-western Madagascar. J. Quat. Sci. 33, 958-968. doi: 10.1002/jqs.3073

Hogg, A. G., Heaton, T. J., Hua, Q., Palmer, J. G., Turney, C. S., Southon, J., et al. (2020). SHCal20 Southern Hemisphere calibration, $0-55,000$ years cal BP. Radiocarbon 62, 759-778. doi: 10.1017/rdc.2020.59

Hua, Q., Barbetti, M., and Rakowski, A. Z. (2013). Atmospheric radiocarbon for the period 1950-2010. Radiocarbon 55, 2059-2072. doi: 10.2458/azu_js_rc.v55i2. 16177

Hyodo, F., Matsumoto, T., Takematsu, Y., Kamoi, T., Fukuda, D., Nakagawa, M., et al. (2010). The structure of a food web in a tropical rain forest in Malaysia based on carbon and nitrogen stable isotope ratios. J. Tropical Ecol. 26, 205-214. doi: 10.1017/s0266467409990502

Jackson, A. L., Inger, R., Parnell, A. C., and Bearhop, S. (2011). Comparing isotopic niche widths among and within communities: SIBER-stable isotope bayesian Ellipses in R. J. Anim. Ecol. 80, 595-602. doi: 10.1111/j.1365-2656.2011.01806.x

Kennett, D., Plog, S., George, R., Culleton, B., Watson, A., Skoglund, P., et al. (2017). Archaeogenomic evidence reveals prehistoric matrilineal dynasty. Nat. Commun. 8:14115. 
Kolby, J. E. (2014). Stop Madagascar's toad invasion now. Nature 509, 563-563. doi: 10.1038/509563a

Kshirsagar, A. R., Applebaum, J. W., Randriana, Z., Rajaonarivelo, T., Rafaliarison, R. R., Farris, Z. J., et al. (2020). Human-dog relationships across communities surrounding ranomafana and Andasibe-Mantadia National Parks, Madagascar. J. Ethnobiol. 40, 483-498.

Laundré, J. W., Hernández, L., and Ripple, W. J. (2010). The landscape of fear: ecological implications of being afraid. Open Ecol. J. 3, 1-7. doi: 10.2174/ 1874213001003030001

Lenth, B. E., Knight, R. L., and Brennan, M. E. (2008). The effects of dogs on wildlife communities. Nat. Areas J. 28, 218-227. doi: 10.3375/0885-8608(2008)28[218: teodow]2.0.co;2

Lohse, J. C., Culleton, B. J., Black, S. L., and Kennett, D. J. (2014). A precise chronology of middle to late holocene bison exploitation in the far southern great plains. J. Texas Archaeol. History 1, 94-126.

Loudon, J. E., Grobler, J. P., Sponheimer, M., Moyer, K., Lorenz, J. G., and Turner, T. R. (2014). Using the stable carbon and nitrogen isotope compositions of vervet monkeys (Chlorocebus pygerythrus) to examine questions in ethnoprimatology. PloS One 9:e100758. doi: 10.1371/journal.pone.0100758

Marshall, J. D., Brooks, J. R., and Lajtha, K. (2007). Sources of variation in the stable isotopic composition of plants in Stable Isotopes in Ecology and Environmental science. Hoboken, NJ: Blackwell Publishing, 22-60.

McCutchan, J. H., Lewis, W. M., Kendall, C., and McGrath, C. C. (2003). Variation in trophic shift for stable isotope ratios of carbon, nitrogen, and sulfur. Oikos 102, 378-390. doi: 10.1034/j.1600-0706.2003.12098.x

McKinney, M. L. (1997). Extinction vulnerability and selectivity: combining ecological and paleontological views. Ann. Rev. Ecol. Syst. 28, 495-516. doi: 10.1146/annurev.ecolsys.28.1.495

McKinney, M. L., and Lockwood, J. L. (1999). Biotic homogenization: a few winners replacing many losers in the next mass extinction. Trends Ecol. Evol. 14, 450-453. doi: 10.1016/s0169-5347(99)01679- 1

Meador, L. R., Godfrey, L. R., Rakotondramavo, J. C., Ranivoharimanana, L., Zamora, A., Sutherland, M. R., et al. (2019). Cryptoprocta spelea (Carnivora: Eupleridae): what did it eat and how do we know? J. Mamm. Evol. 26, 237-251. doi: 10.1007/s10914-017-9391-z

Medina, F. M., Bonnaud, E., Vidal, E., Tershy, B. R., Zavaleta, E. S., Josh Donlan, C., et al. (2011). A global review of the impacts of invasive cats on island endangered vertebrates. Global Change Biol. 17, 3503-3510. doi: 10.1111/j. 1365-2486.2011.02464.x

Merson, S., Dollar, L., Tan, C., and Macdonald, D. W. (2019a). Activity patterns of sympatric living exotic and endemic carnivores (the fosa) in Western Madagascar's deciduous forests. J. Zool. 307, 186-194. doi: 10.1111/jzo. 12630

Merson, S. D., Dollar, L. J., Johnson, P. J., and Macdonald, D. W. (2019b). Retaliatory killing and human perceptions of Madagascar's largest carnivore and livestock predator, the fosa (Cryptoprocta ferox). PloS One 14:e0213341. doi: 10.1371/journal.pone.0213341

Merson, S. D. (2017). Bushmeat hunting, retaliatory killing, habitat degradation and exotic species as threats to Fosa (Cryptoprocta ferox) conservation. Doctoral dissertation. Oxford: University of Oxford.

Middleton, K. (1999). Who killed 'Malagasy cactus'? Science, environment and colonialism in southern Madagascar (1924-1930). J. Southern Afr. Stud. 25, 215-248. doi: 10.1080/030570799108678

Mosher, S. G., Crowley, B. E., Yanes, Y., Diefendorf, A. F., and Barone, R. (2020). Spatial variability in foliar carbon and nitrogen isotope values on tenerife reflects both climate and soils: Establishing a framework for future work. Acta Oecologica 109:103647. doi: 10.1016/j.actao.2020.103647

Nogales, M., Vidal, E., Medina, F. M., Bonnaud, E., Tershy, B. R., Campbell, K. J., et al. (2013). Feral cats and biodiversity conservation: the urgent prioritization of island management. BioScience 63, 804-810. doi: 10.1525/bio.2013.63. 10.7

Nomenjanahary, E. S., Freed, B. Z., Dollar, L. J., Randrianasy, J., and Godfrey, L. R. (2021). The stories people tell, and how they can contribute to our understanding of megafaunal decline and extinction in Madagascar. Malagasy Nat. 15.

Petit, M. G. (1933). "Remarques suggérées par la découverte d'un crâne de Chat dans les dépôts subfossiles de Madagascar", in: Comptes rendus hebdomadaires des séances de l'. Paris: Académie des sciences, 1349-1351.
Pierron, D., Heiske, M., Razafindrazaka, H., Rakoto, I., Rabetokotany, N., Ravololomanga, B., et al. (2017). Genomic landscape of human diversity across Madagascar. Proc. Natl. Acad. Sci. 114, E6498-E6506.

Pomerantz, J., Rasambainarivo, F. T., Dollar, L., Rahajanirina, L. P., Andrianaivoarivelo, R., Parker, P., et al. (2016). Prevalence of antibodies to selected viruses and parasites in introduced and endemic carnivores in western Madagascar. J. Wildlife Dis. 52, 544-552. doi: 10.7589/2015-03-063

Radimilahy, C. (1998). Mahilaka: An archaeological investigation of an early town in northwestern Madagascar. PhD. Sweden: Acta Universitatis Upsaliensis.

Rajeev, M., Edosoa, G., Hanitriniaina, C., Andriamandimby, S. F., Guis, H., Ramiandrasoa, R., et al. (2019). Healthcare utilization, provisioning of postexposure prophylaxis, and estimation of human rabies burden in Madagascar. Vaccine 37, A35-A44.

Rakotozafy, L., and Goodman, S. (2005). Contribution à l'étude zooarchéologique de la région du Sud-ouest et extrême Sud de Madagascar sur la base des collections de l'ICMAA de l'Université d'Antananarivo. Taloha 17, 14-15.

Rasambainarivo, F., Farris, Z. J., Andrianalizah, H., and Parker, P. G. (2017). Interactions between carnivores in Madagascar and the risk of disease transmission. EcoHealth 14, 691-703. doi: 10.1007/s10393-017-1280-7

Rasamuel, D. (1984). Alimentation et techniques anciennes dans le sud Malgache à travers une fosse à ordures du XIe siècle. Etudes Océan Indien 4, 81-109.

Rasoloarison, R., Rasolonandrasana, B., Ganzhorn, J., and Goodman, S. (1995). Predation on vertebrates in the kirindy forest, western Madagascar. Ecotropica $1,59-65$.

Réau, B. (2002). Burning for zebu: the complexity of deforestation issues in western Madagascar. Norsk Geografisk Tidsskrift 56, 219-229. doi: 10.1080/ 00291950260293048

Reid, R. E., and Koch, P. L. (2017). Isotopic ecology of coyotes from scat and road kill carcasses: a complementary approach to feeding experiments. PloS One 12:e0174897. doi: 10.1371/journal.pone.0174897

Ritchie, E. G., Dickman, C. R., Letnic, M., Vanak, A. T., and Gommper, M. (2014). "Dogs as predators and trophic regulators," in Free-ranging dogs and wildlife conservation, ed. M. Gomppe (Oxford: Oxford University Press), 55-68. doi: 10.1093/acprof:osobl/9780199663217.003.0002

Sauther, M., Bertolini, F., Dollar, L., Pomerantz, J., Alves, P., Gandolfi, B., et al. (2020). Taxonomic identification of Madagascar's free-ranging "forest cats". Conserv. Genet. 21, 443-451.

Serpell, J., and Barrett, P. (2017). The domestic dog. Cambridge: Cambridge University Press.

Sparks, J. M., and Crowley, B. E. (2018). Where did people forage in prehistoric Trinidad? Testing the utility of a multi-isotope approach for tracking the origins of terrestrial prey. J. Archaeol. Sci. Rep. 19, 968-978. doi: 10.1016/j.jasrep.2017. 08.002

Stafford, T. W., Brendel, K., and Duhamel, R. C. (1988). Radiocarbon, 13 C and 15 $\mathrm{N}$ analysis of fossil bone: removal of humates with XAD-2 resin. Geochimica et Cosmochimica Acta 52, 2257-2267. doi: 10.1016/0016-7037(88)90128-7

Stafford, T. W., Hare, P. E., Currie, L., Jull, A. T., and Donahue, D. J. (1991). Accelerator radiocarbon dating at the molecular level. J. Archaeol. Sci. 18, 35-72. doi: 10.1016/0305-4403(91)90078-4

Stephens, L., Fuller, D., Boivin, N., Rick, T., Gauthier, N., Kay, A., et al. (2019). Archaeological assessment reveals Earth's early transformation through land use. Science 365, 897-902.

Taborsky, M. (1988). Kiwis and dog predation: observations in waitangi state forest. Notornis 35, 197-202.

Valenta, K., Gettinger-Larson, J. A., Chapman, C. A., and Farris, Z. J. (2016). Barking up the right tree: understanding local attitudes towards dogs in villages surrounding Ranomafana National Park, Madagascar can benefit applied conservation. Madagascar Conserv. Dev. 11, 87-90. doi: 10.4314/mcd.v11i2.4

Van Klinken, G. J. (1999). Bone collagen quality indicators for palaeodietary and radiocarbon measurements. J. Archaeol. Sci. 26, 687-695. doi: 10.1006/jasc. 1998.0385

Vérin, P., and Battistini, R. (1971). Les anciens habitats de Rezoky et d'Asambalahy. Taloha 4, 29-49.

Virah-Sawmy, M., Gillson, L., Gardner, C. J., Anderson, A., Clark, G., and Haberle, S. (2016). A landscape vulnerability framework for identifying integrated conservation and adaptation pathways to climate change: the case of Madagascar's spiny forest. Landscape Ecol. 31, 637-654. doi: 10.1007/s10980015-0269-2 
Virah-Sawmy, M., Willis, K. J., and Gillson, L. (2010). Evidence for drought and forest declines during the recent megafaunal extinctions in Madagascar. J. Biogeogr. 37, 506-519. doi: 10.1111/j.1365-2699.2009.02203.x

Wright, P. C., Heckscher, K., and Dunham, A. E. (1997). Predation on MilneEdward's sifaka (Propithecus diadema edwardsi) by the fossa (Cryptoprocta ferox) in the rain forest of southeastern Madagascar. Folia Primatol. 68, 34-43. doi: 10.1159/000157230

Wyza, E., Dollar, L., Rahajanirina, L. P., Popescu, V., and Stevens, N. J. (2020). Spatial dynamics and activity patterns of the fosa Cryptoprocta ferox in Ankarafantsika National Park, Madagascar: carnivores navigating a human-influenced landscape. Oryx 54, 837-846. doi: 10.1017/s003060531900 0498

Young, J. K., Olson, K. A., Reading, R. P., Amgalanbaatar, S., and Berger, J. (2011). Is wildlife going to the dogs? Impacts of feral and free-roaming dogs on wildlife populations. BioScience 61, 125-132. doi: 10.1525/bio.2011. 61.2.7

Conflict of Interest: The authors declare that the research was conducted in the absence of any commercial or financial relationships that could be construed as a potential conflict of interest.

Copyright (C) 2021 Hixon, Douglass, Godfrey, Eccles, Crowley, Rakotozafy, Clark, Haberle, Anderson, Wright and Kennett. This is an open-access article distributed under the terms of the Creative Commons Attribution License (CC BY). The use, distribution or reproduction in other forums is permitted, provided the original author(s) and the copyright owner(s) are credited and that the original publication in this journal is cited, in accordance with accepted academic practice. No use, distribution or reproduction is permitted which does not comply with these terms. 